\title{
Russian Anecdotes on the "Corona" Theme: Problematics and Poetics
}

\section{Elena E. Zavyalova}

Astrakhan State University. Astrakhan, Russia. Email: zavyalovaelena[at]mail.ru

\section{Abstract}

The article deals with an issue of the widespread distribution of anecdotes about the COVID-19 pandemic in Russia and demonstrates the relevance and necessity of theoretical understanding of this phenomenon. The importance of the research problem is due to the need of recreating the models of situation perception which are reflected in the texts as well as tracing public reaction to the current events and ideological attitudes. The research aim is to identify the peculiarities of the problematics and poetics of the anecdotes about coronavirus infection. The analysis of the regularities in functioning of humorous miniatures shows that a number of genre-forming features of an anecdote are partially restored due to digital technologies. The study reveals that witticisms adapt to the changed communication conditions. Under the conditions of a declared emergency, the electronic method of information transmission sometimes becomes the only possible option. The problematic of anecdotes relevant during the period of 2020 and 2021 indicates that collective consciousness is sensitive to manifestations of the epidemic process. The article lists and characterizes the main thematic groups of anecdotes, their leading motifs and images. Obsessions with eroticism as well as the focus on violation of official taboos are noted. The study found that the actualization of the idea of national identity is an effective way of getting positive emotions. The findings include the figures of speech and expressive means that form the automatism of perception and its unexpected destruction in the final formulas. The article concludes by identifying the literary device of anthropomorphization of the coronavirus image as well as the key functions of the "COVID-19" anecdotes, including communicative, compensatory, psychotherapeutic and harmonizing functions.

Keywords

Anecdote; Coronavirus; Pandemic; Collective Consciousness; Media Space; Comic; Carnivalization; Taboo Violation; Russian Mentality; National Identity

This work is licensed under a Creative Commons «Attribution» 4.0 International License 


\section{Российские анекдоты на «коронную» тему: проблематика и поэтика}

\section{Завьялова Елена Евгеньевна}

Астраханский государственный университет. Астрахань, Россия.

Email: zavyalovaelena[at]mail.ru

\section{Аннотация}

В статье речь идет о широком распространении в России анекдотов и шуток на тему пандемии COVID-19, а также обосновывается необходимость теоретического осмысления данного феномена. Подчёркивается, что важность проблемы обусловлена потребностью воссоздать отражённые в текстах модели восприятия ситуации, проследить реакцию населения на текущие события и идеологические установки и расширить границы интерпретации современной российской культуры. Цель исследования заключается в выявлении особенностей проблематики и поэтики анекдотов про коронавирусную инфекцию. Анализ закономерностей функционирования юмористических миниатюр показывает, что благодаря цифровым технологиям частично восстанавливается ряд жанрообразующих признаков анекдота. Остроты адаптируются к изменившимся коммуникативным условиям, при этом увеличивается скорость распространения текстов, охват аудитории, привносятся объекты и звуки из дополненной реальности. В условиях объявленной чрезвычайной ситуации дистанционный способ передачи информации порой становится единственно возможным. Проблематика актуальных в 2020-2021 гг. анекдотов свидетельствует, что массовое сознание чутко реагирует на проявления эпидемического процесса. В работе перечисляются и характеризуются основные тематические группы шуток, ведущие мотивы, образы. Подчёркивается значимость традиции инверсирования, отмечаются сосредоточенность на эротизме, а также установка на нарушение официальных табу. Указывается, что действенным способом получения позитивных эмоций становится актуализация идеи национальной идентичности, общности. Выделяются изобразительно-выразительные средства, формирующие автоматизм восприятия и неожиданное его разрушение в финальных формулах. Называется специфический приём - антропоморфизация образа вируса. Делается вывод о ключевых функциях анекдотов на «ковидную» тему: коммуникативной, компенсаторной, психотерапевтической и гармонизирующей.

\section{Ключевые слова}

анекдот; коронавирус; пандемия; массовое сознание; медиапространство; комическое; карнавализация; нарушение табу; российский менталитет; национальная идентичность

Это произведение доступно по лицензии Creative Commons «Attribution» («Атрибуция») 4.0 Всемирная 
Судя по количеству анекдотов, мемов и прочих приколов, такой весёлой пандемии в мире ещё не было.

\section{Введение}

Пандемия COVID-19 по самым скромным подсчётам лишила жизни несколько миллионов человек. Эпидемия порождает растерянность, гнев, панику. Люди стараются найти пути выхода из диструктивного состояния. В этих условиях включаются защитные механизмы, опирающиеся на формы народной смеховой культуры.

В столь серьёзной ситуации в центре внимания исследователей оказывается «юмор катастрофы»․ Учёные единодушны: шутки про пандемию становятся инструментом общения, ослабления стресса, управления эмоциями, коллективным механизмом психической защиты. Об этом свидетельствуют онлайн-опросы, анализ «электронных» шуток (прежде всего мемов). На их основе отслеживается степень эффективности действия развлекательных постов, как правило, с учётом культурно-национальной специфики: в Италии (Bischetti, Canal \& Bambini, 2021), Испании (Cancelas-Ouviña, 2021), Голландии (Meder, 2020), Румынии (Felecan, 2021), Польше (Stankevich, 2020), Турции (Saricali, Satici \& Satici et al., 2020), Иордании (Hussein \& Aljamili, 2020), США (Olah \& Ford, 2021; Outley, Bowen \& Pinckney, 2021), России (Мусийчук, 2020; Ахметова, 2020) и др.

Устанавливается связь между эмоциональной реакцией людей на «коронавирусный» юмор и демографическими факторами (возрастом, полом, образованием), а также степенью вовлечённости в события, личностными предрасположенностями (Bischetti, Canal \& Bambini, 2021). Поднимаются этические проблемы: допустим ли смех над эпидемией, вернее - над смертельной болезнью (Miczo, 2021). Изучаются конкретные разновидности современного фольклора, к примеру, мемы, созданные на «масочную» тему (Dynel, 2021), или мемы, отсылающие к воспоминаниям о социалистическом прошлом Польши (Chłopicki \& Brzozowska, 2021).

В России в большей степени востребованным остаётся жанр анекдота, о чём свидетельствует появление огромного количества шуток про COVID-19. Актуальность нашего исследования обусловлена необходимостью теоретического осмысления этого феномена, которое позволит:

- воссоздать отражённые в текстах модели восприятия ситуации;

- проследить реакцию населения на текущие события и идеологические установки;

- обозначить ценности, коими руководствуется массовое сознание;

1 Термин Г. Кёйперс (Kuipers, 2002). 
- оценить роль архаики в коллективных представлениях;

- расширить границы интерпретации современной российской культуры и в определённой степени спрогнозировать вектор её развития в будущем.

Соответственно, цель предпринятых разысканий - выявление особенностей проблематики и поэтики анекдотов, посвящённых теме коронавирусной инфекции.

К настоящему времени накопилось много исследований указанного типа миниатюр. Наиболее значимые из них - труды Н.Ф. Сумцова, А.А. Потебни, А.Н. Веселовского, Д.К. Зеленина, М.А. Петровского, Ю.М. Соколова, В.Я. Проппа, В.Е. Гусева, Е.М. Мелетинского, Г.Л. Пермякова, А.Ф. Белоусова, О.В. Пушкарёвой, О.А. Чирковой. Но признак, позволяющий безошибочно выделять анекдот из общего фонда юмористических рассказов, до сих пор не найден (Пропп, 1984, с. 18). Хотя главные черты жанра указаны: базовая интенция (рассмешить), краткость, двуплановость (Карасик, 1997, с. 145) и связанная с ней неожиданная развязка, определяемая учёными как смена регистра, поворот ситуации, закон пуанты и т.п.

Проанализированы тенденции, характерные для бытования анекдотов в отдельные эпохи: XIX века, советского периода, времени перестройки, начала нового тысячелетия. Но нет работ, посвящённых целостному рассмотрению современных форм. Ещё не осмыслены закономерности их функционирования в условиях нынешнего глобального вызова. Согласно нашей гипотезе, динамика появления текстов соотносится с развитием ключевых фаз пандемии, активное продуцирование наблюдается в периоды ужесточения ограничительных мер.

Фактическим материалом анализа послужили тексты, зафиксированные на русских сайтах Интернета, пересылаемые через мессенджеры, услышанные от информантов. Общий объём корпуса составил более 1200 единиц. Не учитывались формы, выдаваемые за анекдоты, но не соответствующие жанру: афоризмы, новостные сообщения, в том числе фейковые, нарративы «случай из жизни», иронические рассуждения и т.п. - всего около $25 \%$. Дифференцировались картинки с надписями (мемы, демотиваторы) и миниатюры, снабжённые иллюстрациями. Текст анекдота обладает самодостаточностью, встречается как с визуальным сопровождением, так и без такового, поэтому дополнительными критериями отбора стали объём и степень спаянности вербального компонента с изображением.

\section{Функционирование жанра в медиапространстве}

Анекдот - в современном понимании термина - считался сугубо фольклорным жанром. Поскольку ему свойственны: коллективность создания и распространения (Александрова, 2008, с. 14-15); устность; вариативность; 
форма живого контакта с аудиторией. Развитие средств массовой коммуникации постепенно меняет среду его функционирования. Чаще появляются специальные рубрики в периодических изданиях; потом начинают выпускаться многостраничные тематические сборники. В распространении анекдотов всё очевиднее становится роль ТВ-передач. «Ничейные» тексты используют в юмористических киножурналах («Фитиль», 1962, «Ералаш», 1974), миниатюрах артистов разговорного жанра («Аншлаг», 1987, «Смехопанорама», 1994, «Кривое зеркало», 2002). Организуются телевечера («Клуб "Белый попугай"», 1993), телеконкурсы, где гости рассказывают смешные истории («Анекдот Шоу», 2018).

Более 200 лет назад А.П. Пельтцер заметил, что анекдот способен трансформироваться в любой художественный жанр, в котором существенным элементом комического является игра слов или игра положений $(1899$, с. 70$)$. Эта мысль остаётся актуальной и в наше время. Особенно органично вписываются прецедентные тексты в формат скетч-шоу, построенных на совокупности коротких сцен («Джентльмен-шоу», 1991, «Городок», 1993, «Осторожно, модерн!», 1996, «Анекдоты», 2004, «6 кадров», 2005, «Одна за всех», 2009). Выпускаются сходные по структуре, но обладающие большим единством комедийные сериалы («33 квадратных метра», 1996, «Вовочка», 2002). Открываются специализированные каналы («Анекдот ТВ», 2016). Правда, сценарная канва постановок не предусматривает наличия рассказчика, который в речевом жанре играет ключевую роль.

В 1990-е гг. россияне начинают осваивать всемирную паутину, растут её мощности и возможности. Как отмечает Е.Я. Курганов, это способствует дальнейшему выживанию искомой формы массовой художественной речи: «Именно благодаря Интернету доступ к анекдоту необычайно ускорился и упростился. Характер распространения анекдотов наконец-то стал соответствовать природе жанра» (1997, с. 8-9). Процесс набирает обороты с ростом числа активных пользователей в социальных медиа. Графические средства невербальной коммуникации (шрифт, символы и т.п.) отчасти компенсируют отсутствие визуального контакта рассказчика со слушателями.

В конце 1990-х гг. А.Г. Левинсон заявляет о серьёзной трансформации анекдота, обусловленной его дефольклоризацией (1999, с. 370). С мнением известного социолога можно согласиться лишь применительно к раннему этапу истории российского Интернета. Действительно, тексты на специализированных развлекательных сайтах подвергаются правке / обработке и цензурному редактированию, т.е. олитературиванию. Помимо этого, утрачиваются такие важные условия функционирования речевого жанра, как ситуативность и уместность (Шмелёва \& Шмелёв, 2002, с. 86).

В начале 2000-х гг. набирает популярность чат-коммуникация, взаимодействие в Интернете, особенно в синхронных его разновидностях, делается всё ближе к устной произвольной речи в её диалогической форме - с присущими этому дискурсу особенностями: непосредственностью, неофициально- 
стью и той самой ситуативностью (Сиротинина, 1974; Земская, Китайгородская \& Ширяев, 1981; Miller \& Weinert, 1998). Как отмечает Е.М. Александрова, «в спонтанных интернетовских чатах отшлифовываются новые способы адекватной адаптации традиционного анекдота к изменившимся коммуникативным условиям (имитация разговорной речи, замена цензурного многоточия эмоциональностью произвольно набранных служебных значков)» (2008, с. 15). T.e. набор предъявляемых к анекдоту требований несколько меняется (Каспэ, 2000 , с. 330), но ряд жанрообразующих признаков оказывается частично восстановлен. Более того, в десятки, сотни раз увеличивается скорость распространения текстов и ширина охвата аудитории.

Пользователи соцсетей (Facebook, 2004, «ВКонтакте», 2006, «Одноклассники», 2006) получают возможность публиковать фотографии, картинки, обмениваться аудио- и видеофайлами. Что позволяет рассказчикам при желании прибегать к фонационным (интонация, ударения, темп речи, паузы) и кинетическим (мимика, жесты, позы) средствам выразительности. Появление видеохостинга (YouTube, 2005) открывает новые перспективы - делиться контентом с миллионной аудиторией. М.А. Уханова доказывает, что сращение вербальных и визуальных компонентов шутки превращает анекдот в единицу медиатекста; «полимодальная природа новых форм анекдота влияет на его языковую репрезентацию» (Уханова, 2020).

Серьёзный шаг вперёд на пути цифровизации - «миграция» пользователей в мобильные устройства. Платформы адаптируются к новым условиям. Например, анекдоты становится возможным не просто читать, но перелистывать по частям; дозированная информация на экране - ещё один вариант имитации пауз рассказчика и подготовки неожиданной развязки. Востребованными оказываются предельная сжатость и точность изложения: небольшой текст анекдота легко умещается на маленьком дисплее.

Распространение мессенджеров (WhatsApp, 2009, Viber, 2010, Telegram, 2013) в определённом смысле возвращает анекдот в стихию народной речи, т.к. системы: 1) способствуют мгновенному обмену информацией (в любое время, почти в любом месте, почти бесплатно); 2) в случае многократной пересылки сведений практически исключают нахождение первоисточника (такая деперсонализация коррелирует с фольклорной анонимностью); 3) обеспечивают трансляцию на широкую, но при этом самостоятельно отобранную аудиторию / избранную группу людей (анекдот часто становится показателем меры личного доверия). Собеседники обмениваются сообщениями, часто случается так, что на отосланный текст человек получает одну или несколько шуток на ту же тему. Так на новом уровне реализуется изначальная жанровая интенция «к постоянным сцеплениям и переплетениям» (Курганов, 1997, с. 53). Рассылка анекдотов - процесс элементарный, в нём способны участвовать те, кто затрудняется воспроизводить тексты устно (из-за проблем с языком, дикцией, памятью и т.п.). Эти, новые, акторы вовлекают других людей, круг сопричастных растёт в геометрической прогрессии. 
Сравнительно молодое мобильное приложение TikTok (2018) позволяет пользователям изготавливать и просматривать короткие видео, приватные аккаунты, присваивать роликам определённый статус. Предпочтения отслеживаются искусственным интеллектом по хештегам, автоматически подбирается персональный контент. Иначе говоря, цифровые сервисы учитывают реакцию слушателя, почти как настоящие рассказчики. «Народность» приложения определяется его доступностью, простотой использования, трендом на антигламурность. B TikTok прочно обосновались видео с представлением / инсценировкой анекдотов. Причин много, основные: лёгкость создания роликов, заложенная в челлендж идея повторения, связанная с ней вариативность, клиповый тип подачи материала, возможность сочетания слова с художественными элементами других видов искусства, с виртуальными образами, объектами и звуками из дополненной реальности (Augmented Reality).

Как показывает наш обзор, в эпоху цифровых трансформаций жанр анекдота не просто адаптируется к изменившимся условиям, но получает возможность для а) более яркой презентации текста; б) его мгновенного и адресного распространения; в) беспрецедентно широкого охвата аудитории, прежде всего, через репостинг; г) полулегального функционирования; д) действенного влияния на общественные убеждения.

\section{Хроникальный эффект}

Реагируя на какое-либо событие, массовое сознание формирует интерсубъектное мнение, на основе которого возникают анекдоты. Поэтому их называют «формой вторичной обработки информации» (Чиркова, 1997, с. 8). Этот процесс легко проследить по смене тематики актуальных в 2020-2021 гг. форм. В них фактически запечатлена вся история распространения новой инфекции и борьбы с эпидемией.

\section{COVID-19: начало}

Т. Медер справедливо отмечает, что, как и вирус, шутки приходили волнами. Первые - не только в России - касались «странных китайцев, которые едят странную пищу, например, летучих мышей» (Meder, 2020, p. 141). Вот пример подобной миниатюры: «Я сегодня посмотрел на живую летучую мышь. Тот, кто догадался это съесть, несомненно, был болен ещё до коронавиpyca».

Поначалу степень аверсивности низка, появляются миниатюры про потенциальную опасность инфицирования: «Получил письмо от приятеля из Италии. В конце он, как всегда, пишет: “Жму руку, обнимаю”. - "Вот же ж $\mathrm{c}^{* * * ! " » . ~ Н е т ~ и н ф о р м а ц и и ~ о ~ ш т а м м а х, ~ н о ~ у п о м и н а ю т с я ~ в а р и а н т ы ~ з а р а ж е н и я ~}$ в разных странах: «"А у тебя коронавирус?" - “Да." - "А он у тебя из Китая или Ирана?” - “Обижаешь, чисто итальянский!”». В дальнейшем отдельной темой становится сложная эпидемиологическая ситуация в столице: «Кажется, скоро 
во всех регионах страны от машин с московскими номерами будут шарахаться, как от всадников Апокалипсиса» 1 . И, наконец, в любом другом уголке России: «Апрель 2020. Думаю, лучше переболеть сейчас, пока есть свободные койки в больницах и здоровые врачи. Май 2020. Думаю, лучше переболеть сейчас, пока есть свободные места на кладбищах».

Вначале доминирует чувство иронической отстранённости: «В искусственном происхождении COVID-19 не может быть сомнения. Только злой человеческий гений мог объединить судорожный кашель и диарею в одном заболевании». Оно достаточно быстро сменяется ужасом. Предметом многих миниатюр оказывается панический страх перед заражением, порождающий беспримерную жестокость:

В морге:

- А эти двое умерли от ковида.

- Так у одного же череп проломлен...

- Ехал в автобусе без маски и кашлянул.

- А тот, с кочергой в спине?

- Он чихнул возле кочегара...

Кашляющий в общественном транспорте теряет зубы, не доехав до стоматолога. Чихающий у себя дома обнаруживает, что соседи заколотили его входную дверь. А согрешившего таким же образом космонавта переселяют с МКС в открытый космос.

Для провинившихся составляется отдельная статья «кодекса»:

- Кашель одиночный. Карается изоляцией на 14 суток.

- Кашель в общественном месте. От 15 суток до 6 месяцев или штраф 10000 руб.

- Кашель в общественном месте, совершённый с особым цинизмом. От

6 месяцев до 1 года, штраф 50000 руб.

- Кашель, совершённый неоднократно, либо по предварительному сговору группы лиц. От 1 года до 3 лет.

- Кашель в отношении должностного лица, квалифицируемый по статье «терроризм». 8 лет строго режима.

Другие варианты развития событий - имитация болезни в корыстных целях и использование ситуации для сокрытия правды. В первом случае рассказывается о новом виде ограбления, когда бандит угрожает чихнуть на улице, в магазине, банке. О современной психической атаке, при которой солдаты идут на противника ровным строем, чихая. О сенсационном «смертельном» номере циркового клоуна, кашляющего с арены на первый ряд. Во втором - смерть от коронавируса диагностируется наряду с «сопутствующими заболеваниями»: гематомами по всему телу, огнестрелом, вилами и топором в спине.

1 Во время первой волны COVID-19 опасность столицы как очага заболевания является проблемой, вызывающей тревогу у большинства населения мира. 


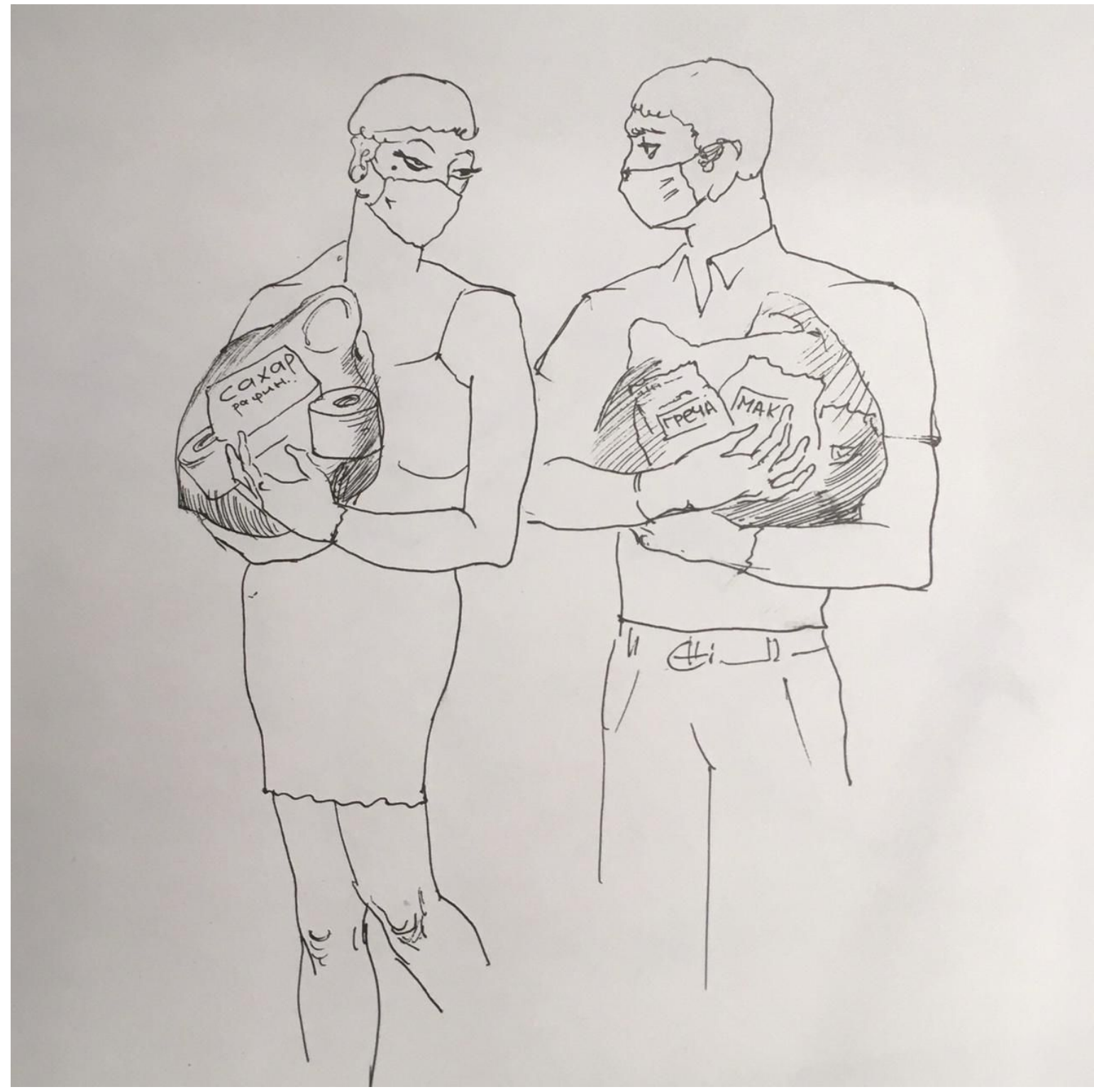

Рис. 1. Художник Spessiva

Fig 1. Artist Spessiva

Обращают на себя внимание непривычные симптомы болезни. Большинство таких историй носит раблезианский характер. Рассказы о тестировании вкусовых рецепторов чаще всего посвящены ночным пиршествам на кухне. Незамысловаты анекдоты на тему проверки обоняния (как правило, в общественном транспорте) и искажении запахов ${ }^{1}$.

В контексте характерных для жанра карнавальных инверсий интерес представляют анекдоты о панических закупках туалетной бумаги и провизии: «Никто не подскажет, сколько рулонов туалетной бумаги брать из расчёта на 10 кг гречки?»; «Почитал я все новости про коронавирус и понял, как надо

1 Ср. со сравнительно новым, изящным вариантом: «Первый признак, что вы заражены индийским штаммом: все запахи меняются на запах карри». 
излечиваться: купить килограмм имбиря, упаковку туалетной бумаги, сесть на унитаз и сидеть, не слезая, две недели»; «Мужчина с запасом гречки и макарон познакомится с женщиной с запасом сахара и туалетной бумаги». «Круглая радость» объявляется новой валютой. Её охраняют инкассаторы, кладут на депозит в банк, обменивают на квартиры. Если составлять рейтинг пищевых продуктов, упоминаемых в российских анекдотах, на первом месте по популярности окажется гречка, далее тушёнка, имбирь, макароны, лимоны, чеснок. Вырисовывается вполне правдоподобная картина поведения отечественного потребителя.

\section{Профилактические меры}

Первоначальный ажиотаж на медицинские маски обусловливает появление шуток на тему их дефицита: «"Добрый день! Мне маску". - "Масок нет. Возьмите салют. Это красиво"». Не остаётся без внимания и проблема штрафов: «Дожили! Платим за воздух! Тариф “Дышим в маске” - 30 руб. Тариф “Дышим без маски" - 5000 руб.». С течением времени популярными становятся анекдоты про заношенные одноразовые маски.

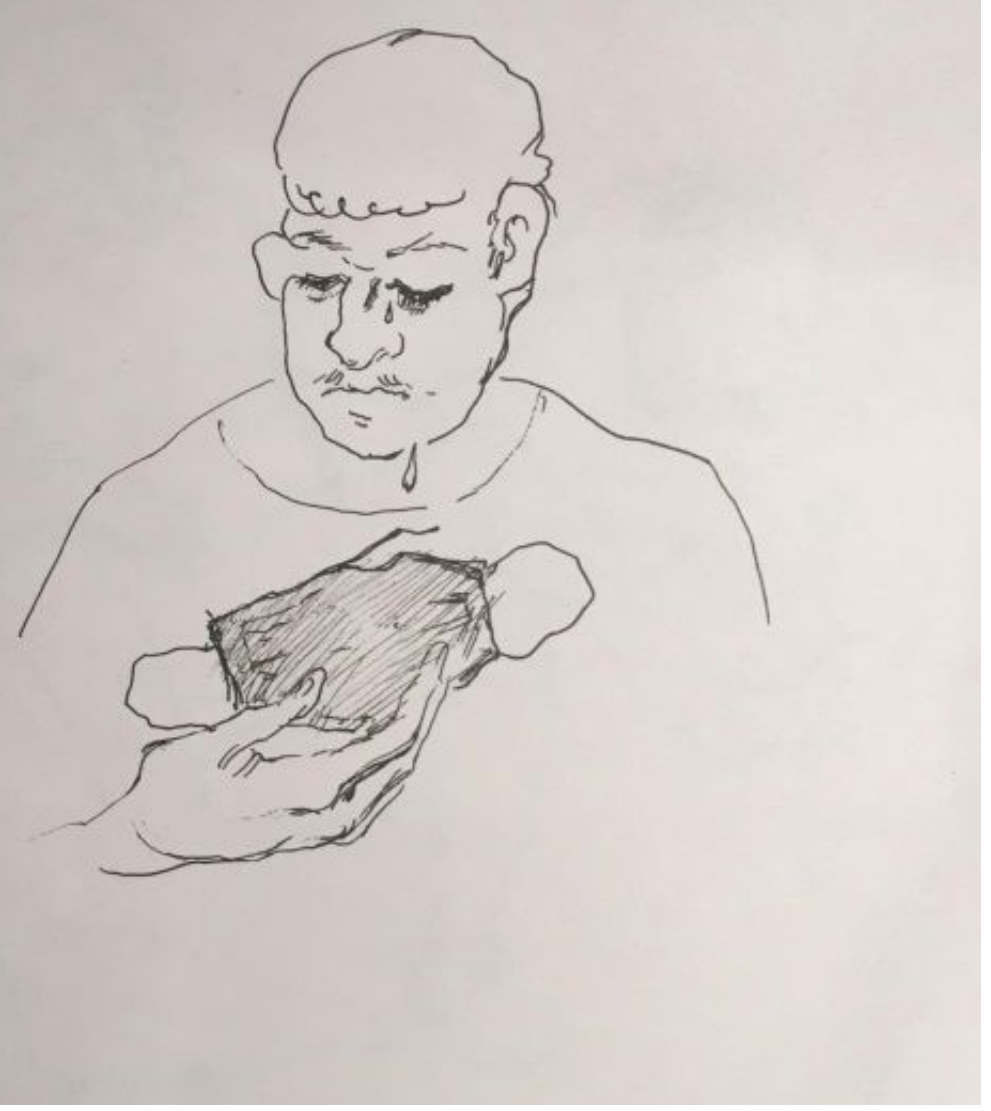

Рис. 2. Художник Spessiva

Fig 2. Artist Spessiva 
«Есть вопрос! Может, кто с таким уже сталкивался? Если в маске поломалась проволока, можно ли её как-то поменять или это уже всё?»

«Продам маску б/у в хорошем состоянии. Один хозяин, не шитая, не стиранная, пробег 10 км, требует замены левой резинки. Цена 3 рубля, торг при осмотре».

«У моей единственной маски сегодня юбилей! Ровно 100 дней ношения! Отметил стиркой!»

«"А вы помните свою самую первую маску?” - “Что за дурацкий вопрос? Я в ней хожу"».

«"У вас маска одноразовая или многоразовая?" - "Одноразовая, но многоразового использования"».

Использовать маски неудобно: шашлык в них не жуётся, кальян не курится; в довершение существует вероятность отравиться собственным перегаром. В то же время эти средства защиты дают массу преимуществ: можно замачивать их в спирте для хорошего настроения, прятать улыбку либо её отсутствие, поддерживать отвисающую челюсть, в пикантной ситуации оставаться неузнанным одноклассницей, женой или тёщей.

Ряд анекдотов построен на сопоставлении значений лексемы 'маска' («предохранительная», «камуфляжная», «маскарадная», «косметическая»). Развивается ситуация «человек в маске у кассы в магазине / в банке»: сравнивается реакция охраны в доковидное и нынешнее время, описываются ощущения клиентов, примеряющих на себя роль налётчика. Частотна ситуация «маска, надетая / снятая по недоразумению»: женщина с наложенными на лицо огурцами, мать в обличии крокодила на детсадовском утреннике, сварщик, хоккейный вратарь, фехтовальщик (в последних двух случаях вводится дополнительная деталь - перчатки).

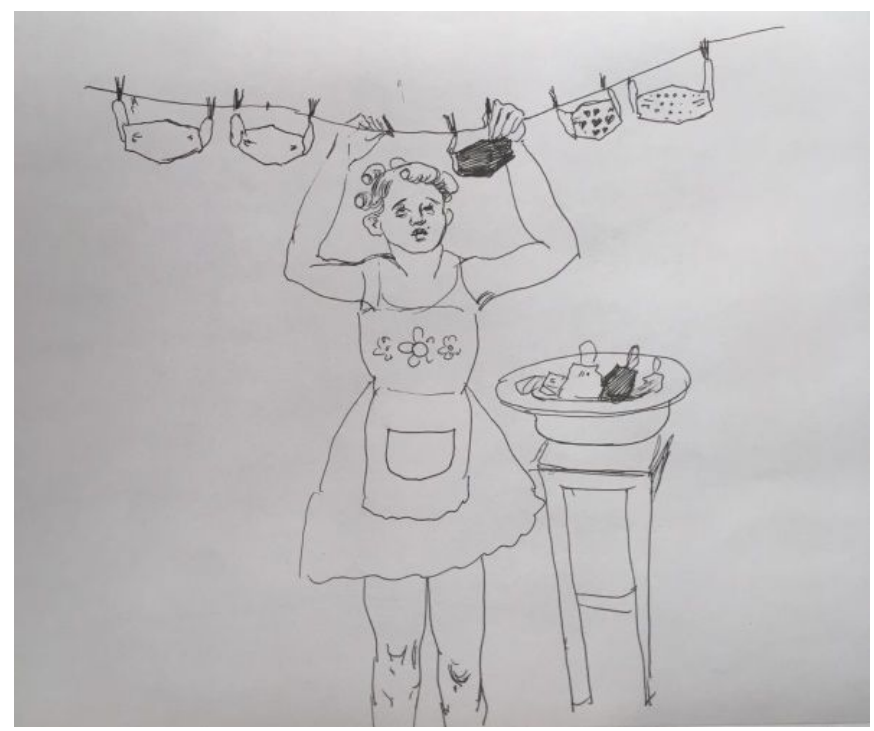

Рис. 3. Художник Spessiva

Fig 3. Artist Spessiva 
Активно обыгрывается метонимия маска / лицо: «"Как прошёл новогодний корпоратив?" - “Так себе, ни одной симпатичной маски”»; «“Дайте мне, пожалуйста, две банки чёрной икры". - “А у тебя маска не треснет?”».

Примечательно существование значительного количества миниатюр, в которых маска сопоставляется с другим медицинским изделием: «Глядя на то, как люди носят маски, я стал понимать, почему презервативы не помогают»; «Раньше под окнами общежития валялись одни одноразовые средства индивидуальной защиты, сейчас другие»; «“Достаточно ли маски, чтобы защититься от короновируса?" - "Недостаточно! Презерватив тоже нужен"». Вновь необходимо подчеркнуть значимость архаической традиции инверсирования, карнавальную сосредоточенность на эротизме. Она находит выражение и в шутках о голых: «Не верьте никому! Особенно Минздраву! Сказали, чтобы выйти в магазин, достаточно надеть маску и перчатки. Я так и сделал..., а люди... - c*** - надели ещё и брюки, и куртки!..»

К указанной группе относим также анекдоты, в которых лицо («верх») косвенно соотносится с телесным «низом»: «Мы носим маски так долго, что скоро нос станет элементом эротики»; «На эпиляции было очень странно лежать в маске, но без трусов»; «В банке предъявил паспорт, попросили опустить маску. Возникло ощущение, как если бы штаны попросили спустить»; «"Где ваша маска?" - "У меня маска-стринги". - "Но она же ничего не закрывает". - "А трусы стринги много закрывают?"». М.М. Бахтин указывает: «В собственно телесном аспекте, который нигде чётко не отграничен от космического, верх - это лицо (голова), низ - производительные органы, живот и зад. С этими абсолютными топографическими значениями верха и низа и работает гротескный реализм...» $(1990$, с. 28). В мифологическом смысле снижение имеет амбивалентное значение: сбрасывание в небытие - и зачатие, новое рождение.

В анекдотах запечатлеваются практически все формы профилактики заболевания. Дезинфекция: «Нравится мне, что везде стоят дозаторы с антисептиком! Не то, чтобы я сильно заботился о здоровье, просто люблю зловеще потирать руки». Термометрия: «Охраннику в супермаркете не выдали термометр, и он при входе просто всех целовал в лоб». Сохранение безопасного расстояния между людьми: «Петрович таки не смог удержать социальную дистанцию, находясь у соседки, у которой социальная ответственность имеет критически низкий уровень».

Отдельная тема - отечественные тест-системы. Сначала изобличается их дефицит: «"Мы закупили большую партию тестов!" - "Так они же на беременность!" - “Других не было”». Позднее критикуется некачественность диагностики: «"Что это у вас тут так воняет?" - "Новейшая разработка наших учёных, опытный образец. Бестемпературно-рецепторный тест на COVID. Определяет наличие вируса на этапе отёка, ещё до повышения температуры". - "Вот это да! Вы серьёзно?" - "Нет! Мышь сдохла, второй день найти не можем..."»; «“Алло! Здравствуйте, Людмила Алексеевна! Горздравнадзор. Тестирование на корона- 
вирус. Вы больны коронавирусом?" - "Нет!" - "Спасибо! Вы прошли тест! У вас отрицательный”» «“Доктор, но у меня же две ноги!” - “А тест показывает, что вы бессимптомно одноногий"».

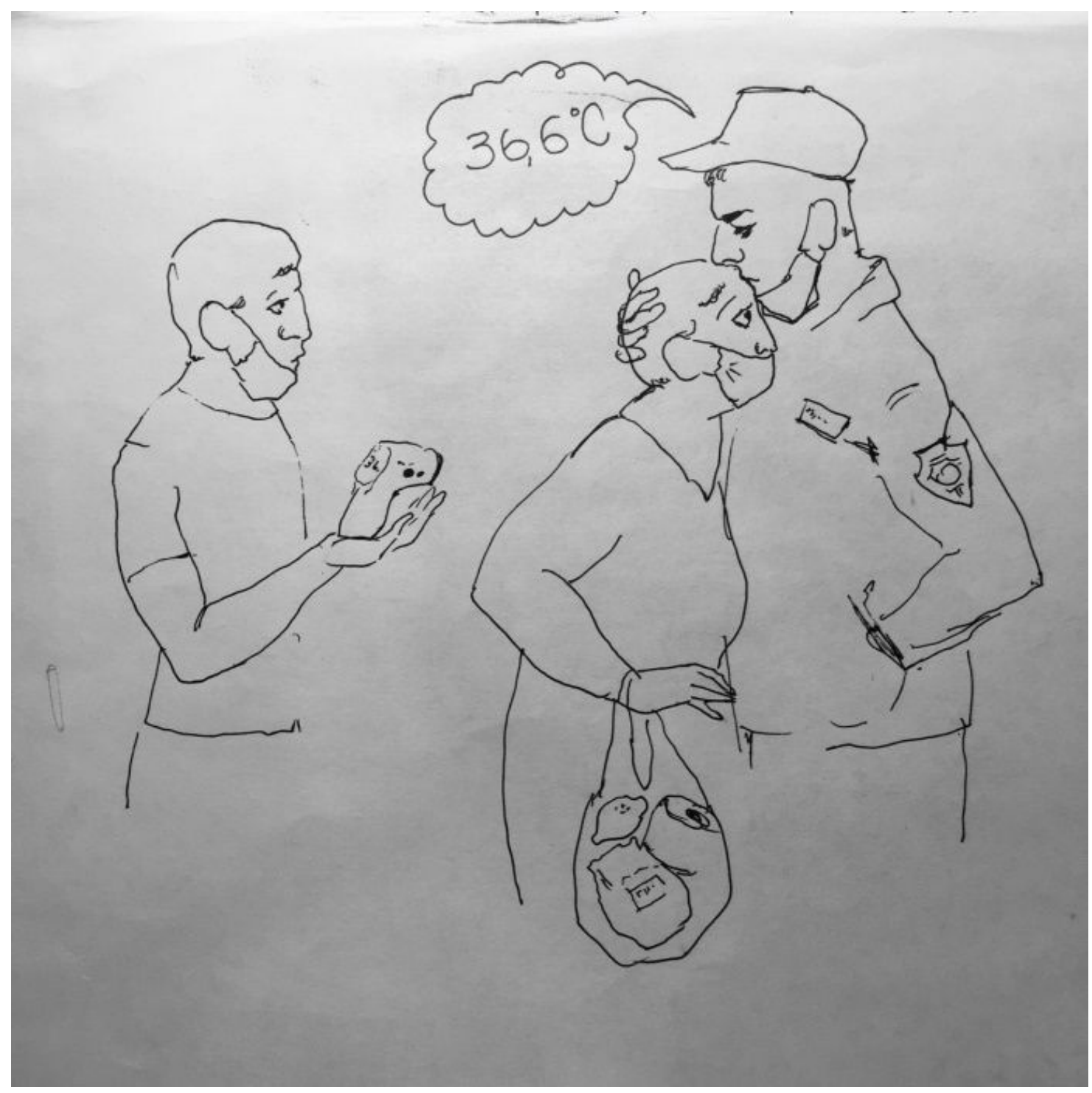

Рис. 4. Художник Spessiva

Fig 4. Artist Spessiva

\section{Издержки изоляции}

Широкий резонанс получает введение режима самоизоляции. Выражается недовольство мерами принуждения: «Полстраны дома сидит, а вторая половина их охраняет». Быстро появляются «советы» о способах преодоления ограничений: выгуливание мусорного пакета, работа волонтёра по предупреждению дефилирующих, аренда костюма доставщика еды, организация 
похорон гуся (курицы, сазана) - с целью пригласить в гости знакомых больше, чем установлено правилами.

Запрет выгула собак на расстоянии более 100 метров от дома порождает много остроумных объяснений: «На самом деле коронавирус придумали собаки, чтобы с ними целыми днями гуляли на улице»; «Стало известно, зачем нужно носить с собой паспорт: тот, кто родился в год собаки, может гулять в парке сам»; «"А вот скажите, на земле вирус может быть? Собака принести может?" - "Если собака гуляет в пределах 100 метров от дома, то нет, конечно. Но как только она ступит за 101-й метр..."» Большое количество текстов посвящено усталым питомцам, обслуживающим многочисленных соседей-бессобачников.

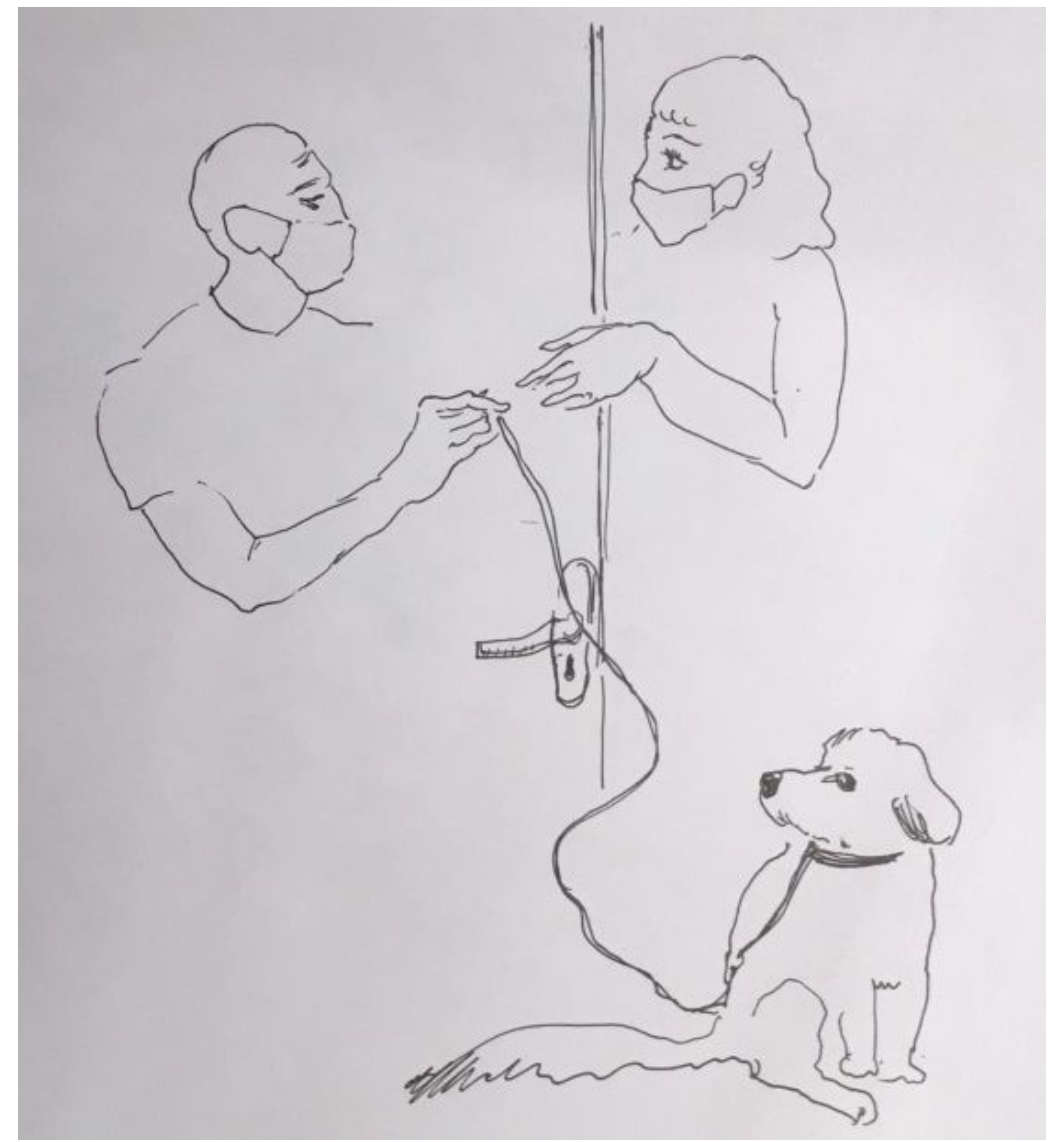

Рис. 5. Художник Spessiva

Fig 5. Artist Spessiva

Один из традиционных приёмов создания комического - обмен ролями. Он часто встречается в анекдотах про псов. Например: «Раньше отлавливали собак без сопровождения человека, теперь отлавливают людей без сопровождения собаки». Активно обыгрывается метафора медицинская маска / намордник: «Собака имеет право выгуливать одного человека. Человек должен 
быть в наморднике, с документом и на поводке». Встречаются и более развёрнутые варианты замещения:

Бегают две собаки на газоне. Молодая спрашивает:

- Слушай, а почему это всю жизнь собаки в намордниках ходили, а люди только сейчас начали их носить?

Старая:

- Да ничего странного! Наши тоже сначала в космос слетали, а потом и люди полетели.

В процитированном примере характерное для комических жанров очеловечивание животного (Пропп, 1999, с. 60) доведено до абсурда: собакам приписываются первенство в научно-технических достижениях. Нелепость порождает смеховой эффект.

«Собачья» тема характеризуется ограниченным ракурсом: выгул животных-компаньонов. Устойчивый мотив анекдотов с участием кошек усталость от постоянного пребывания людей дома. Независимость, «прохладное, ненаигранное» (Shepherd, 2014) поведение хищниц в данном контексте приходятся очень кстати. Тем более - с учётом гиперпопулярности образа в интернет-пространстве. «Мой кот начинает проявлять нервозность, потому что я уже несколько дней постоянно нахожусь в его квартире»; «Пятый день лежу на диване, кот уже видит во мне конкурента»; «Шла пятая неделя самоизоляции... Я: “Как же чертовски скучно!" Кот: “А ты пробовал сидеть на краю стола и скидывать что-нибудь на пол?"». В отмеченной группе текстов животным также приписывается поведение, сходное с человеческим. Вплоть до реакции на ограничительные меры: «Из-за погодных условий и пандемии коты перенесли март на апрель, потом на май, а потом расхотелось».

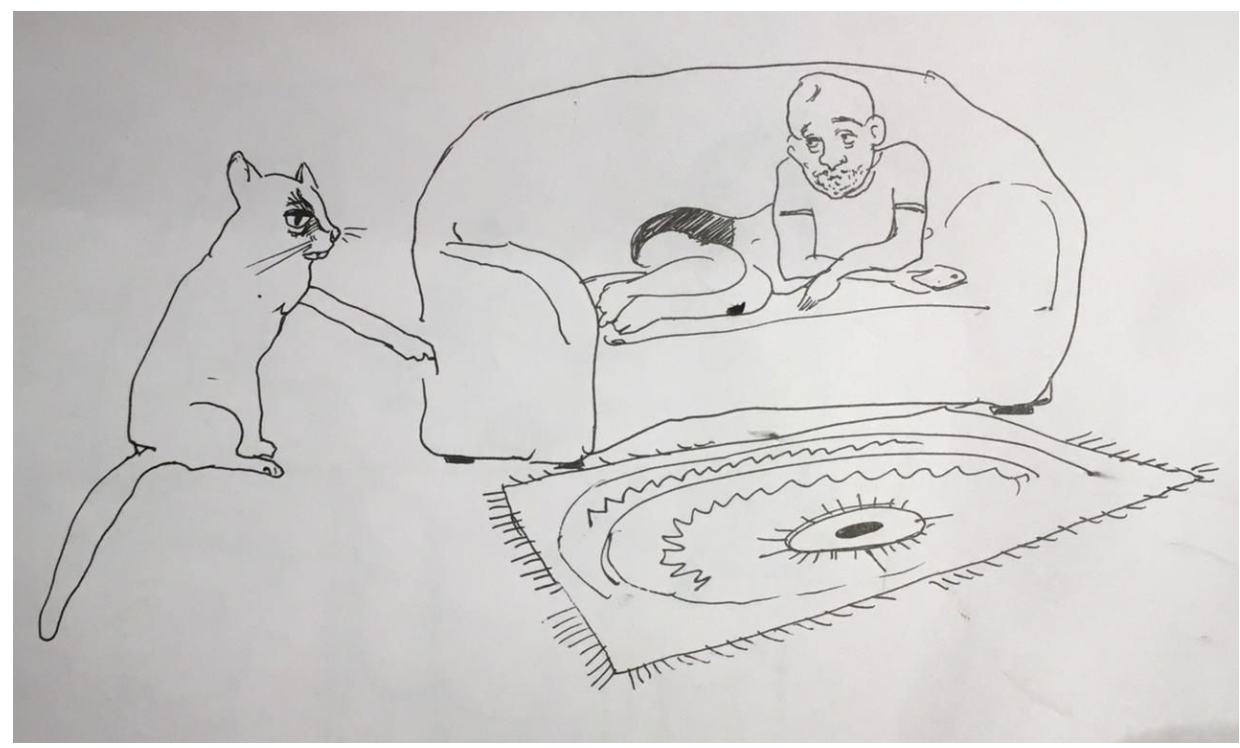

Рис. 6. Художник Spessiva

Fig 6. Artist Spessiva 
Приём доведения ситуации до абсурда используется в анекдотах о занятиях людей, находящихся на самоизоляции. Подсчёт зёрен риса, крупинок гречки в упаковках, философские диспуты с домашними питомцами, полемика с пауком («Хорошо пообщались. Он тоже веб-дизайнер».) В качестве примера текста с логическими нестыковками приведём следующую миниатюру: «"Васька, котик, ты тоже считаешь бредом, что люди на самоизоляции с ума сходят?" - "Я не кот, я - утюг"». Усталость от затворничества выказывается в пародии на слоган рекламной акции: «Всем, кто прожил месяц самоизоляции без нарушений, ещё один месяц в подарок!»

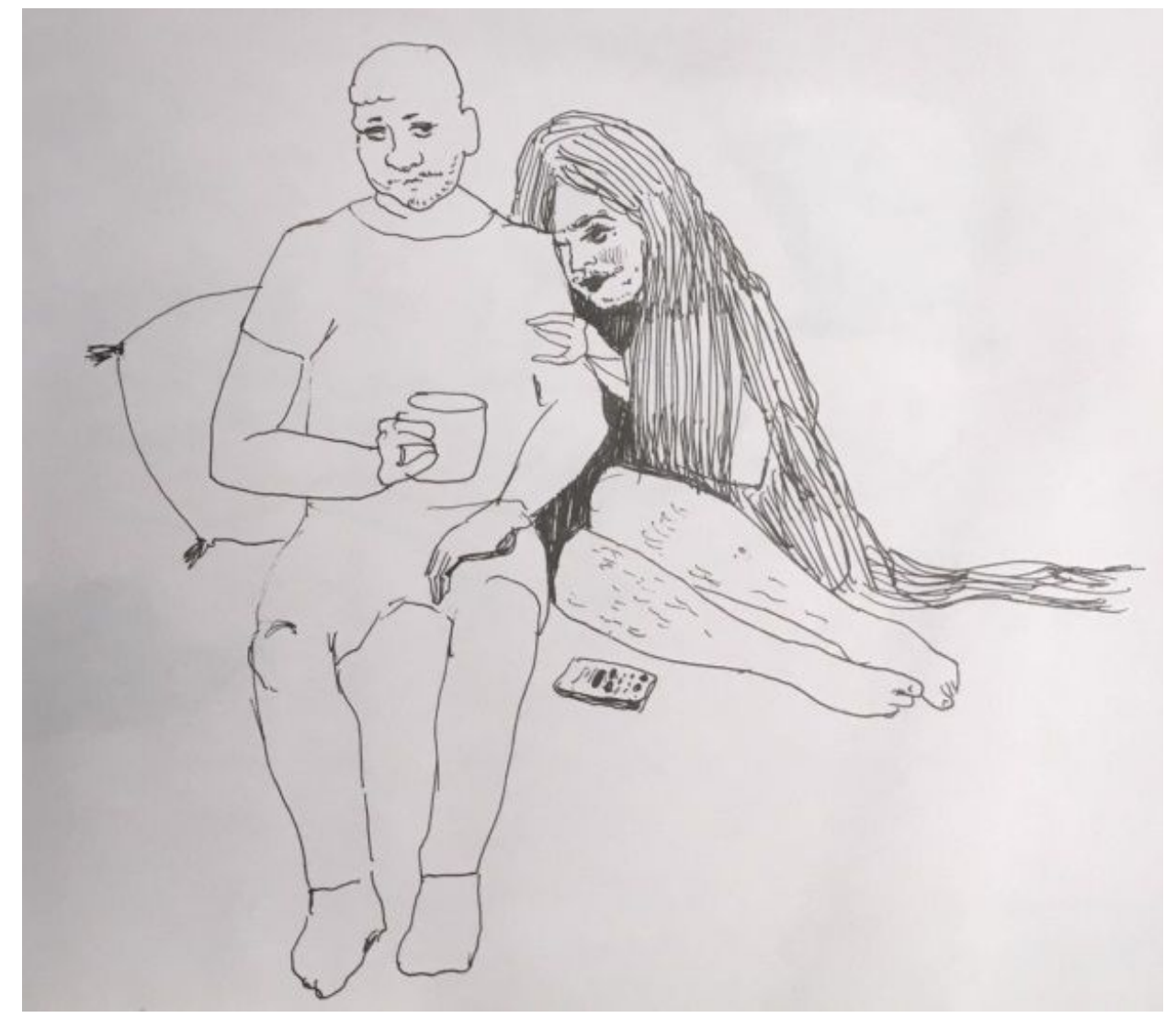

Рис. 7. Художник Spessiva

Fig. 7. Artist Spessiva

Популярна тема последствий закрытия салонов красоты: «Многие, находясь на самоизоляции, вообще перестали за собой следить. Усы топорщатся, бороды клочьями, пивные животы. Жуть. А про мужиков я вообще молчу...». Не менее частотны анекдоты про неконтролируемый набор веса: «После двух месяцев самоизоляции и обжираловки в квартире было обнаружено два антитела». Встречаются миниатюры о фитнес-притонах, подпольных ресторанах, секретных кальянных, парикмахерских, нелегальных школах, музеях.

В двух значительных тематических группах анекдотов, появление которых обусловлено серьёзными изменениями образа жизни сотен миллионов людей, 
рассказывается про удалённую работу и дистанционную учёбу. Главный объект высмеивания в них - человеческая лень, невозможность преодолеть соблазны пребывания дома: «Сейчас моя дорога на работу это путь от кровати до компьютера. Но я всё равно опаздываю. Начинаю подозревать, что причина всё-таки во мне»; «Хочу напомнить главное правило удалённой работы: “Ни в коем случае не садитесь на мягкое! Это ловушка!"»; «Коллеги, мы можем перенести видеоконференцию на 30 минут? у меня форс-мажор: внезапно доварились сардельки».

Ряд текстов посвящён повествованию о принципах работы на расстоянии. Почтальоны читают письма и звонят адресату, если находят что-то важное; стоматологи предлагают воспользоваться сервисом телемедицины, велят приготовить плоскогубцы и дрель; домработницы дают хозяевам указания по телефону. Нет детализации в рассказах о том, как трудятся пилот пассажирского самолёта, рабочий прокатного цеха, патологоанатом: реципиенту предоставляется возможность самостоятельно вообразить подробности.

В анекдотах про обучение преобладают мотивы виртуальной оплаты ремонта и хозяйственных нужд, уничтожения онлайн-школ, беспомощности родителей. Переиначиваются типичные учительские фразы: «Выйди и зайди в скайп нормально», «Папу с мамой быстро к монитору!», «Что за смех? Скинь ссылку, вместе посмеёмся».

На указ об ограничениях, введённых после завершения периода нерабочих дней, креативные граждане реагируют, предлагая свои трактовки: «С 12 мая работать, свободно гулять и ездить на личных авто не только можно, но и нельзя»; «С 12 мая начинаются рабочие дни без сохранения заработной платы»; «Нерабочие дни в России закончились, рабочие пока не начинаются». Потом обыгрывается новость об отмене мер: «С 9 июня все москвичи, которые будут сидеть дома, обязаны заплатить штраф 5000 рублей за нарушение режима отмены режима самоизоляции».

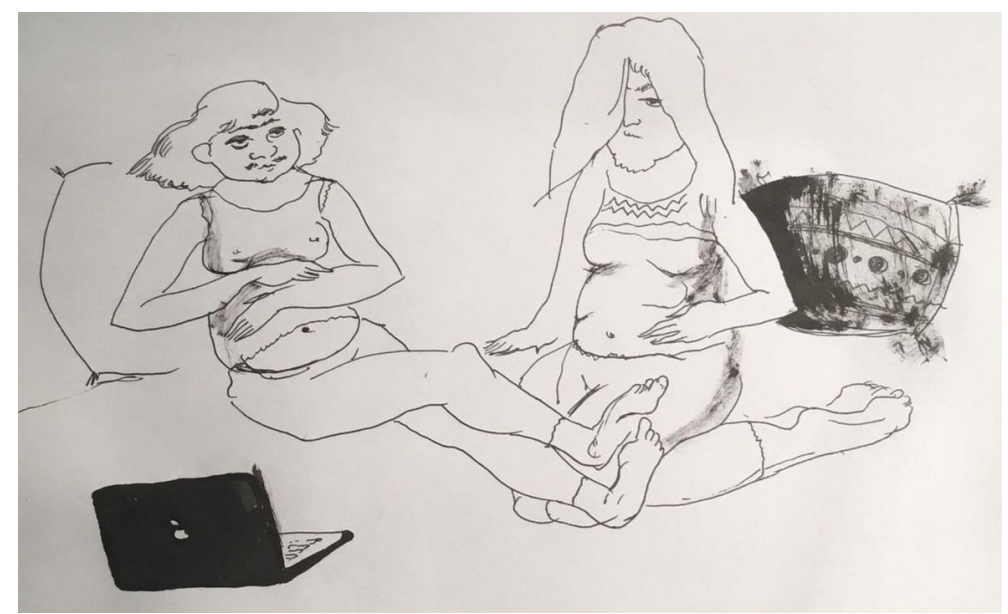

Рис. 8. Художник Spessiva

Fig. 8. Artist Spessiva 
Закрытие границ, запреты на поездки ведут к появлению рассказов об «альтернативных» вариантах отдыха: «Никак не можем определиться, где провести свой следующий отпуск: то ли в гостиной, то ли в спальне»; «Купил себе влажные салфетки с запахом океана и жвачку со вкусом тропических фруктов. А как вы собираетесь отдыхать в этом году?»; «Жена пришла из магазина, принесла несколько бутылок вина - все из разных стран: испанское, французское, грузинское. Говорит: "Раз уж придётся дома сидеть, пусть хоть печень в кругосветное путешествие съездит"».

Карантинные меры (ограничение перемещений, спад производства и проч.) существенно снижают выбросы углекислого газа, что несколько улучшает экологическую ситуацию. Вслед за разлетевшейся по всему миру фейковой новостью «Природа настолько очистилась, что в каналы Венеции вернулись дельфины» появляется много других, построенных по тому же шаблону. Вот несколько российских версий:

«Природа настолько очистилась за время карантина, что в сёла массово возвращаются бариста, маркетологи и тренеры личностного роста».

«Ещё месяц бесконечных выходных, и природа настолько очистится, что в город вернутся сигареты поштучно и семечки в стаканах».

«Природа настолько очистилась, что в интернет вернулась Масяня».

«За время эпидемии кабинет Путина настолько очистился, что в него вернулся Медведев».

«Во время карантина природа России настолько очистилась, что в неё вернулись печенеги и половцы».

«Природа так очистилась, что ко мне вернулись 5 кг, сброшенные в сентябре».

Исследователи, как правило, включают подобные иллюстрированные тексты в обширнейшую группу медиа-вирусов, мемов (Рашкофф, 2003). На наш взгляд, основную массу миниатюр «Природа очистилась...» можно отнести к анекдотам, точнее - к их тематическому ряду.

\section{Выводы рубежного времени}

В соответствии с архаическим мировосприятием завершение календарного цикла является очень важным событием. Потому что в конце старого года все связи распадаются и силы хаоса берут верх, а при наступлении нового побеждает космическое, организующее начало (Топоров \& Иванов, 1974, с. 78). По словам психологов, находясь на финишной прямой, человек склонен подводить итоги и строить планы на будущее. Не удивительно, что в ситуации неопределённости большое количество «ковидных» анекдотов посвящено осмыслению 2020-го и попытке предугадать дальнейшее развитие событий.

Трагические факты связываются с високосностью: «2020-й оказался високоснее всех високосных». Соотносятся с названием года по восточному 
календарю: «Этот год действительно год крысы: сидим по норам, вылезаем за припасами и тащим в норку, увидим человека - разбегаемся...»; «В январе все гадали: что же нам принесёт год крысы? И только историки знали, что крысы обычно приносят чуму». Предлагается эффектный вариант завершения «сезона»: «Я считаю, что в конце года просто обязаны прилететь инопланетяне. У этого экшена должен быть феерический финал». В нескольких миниатюрах обыгрывается мотив прошлогоднего неправильно исполненного желания: получить незабываемые впечатления, больше отдыхать, не ходить на работу, ничего не делать. Новые желания намного скромнее: «"Что ты попросишь у Деда Мороза в новом 2021 году?" - "Пощады”».

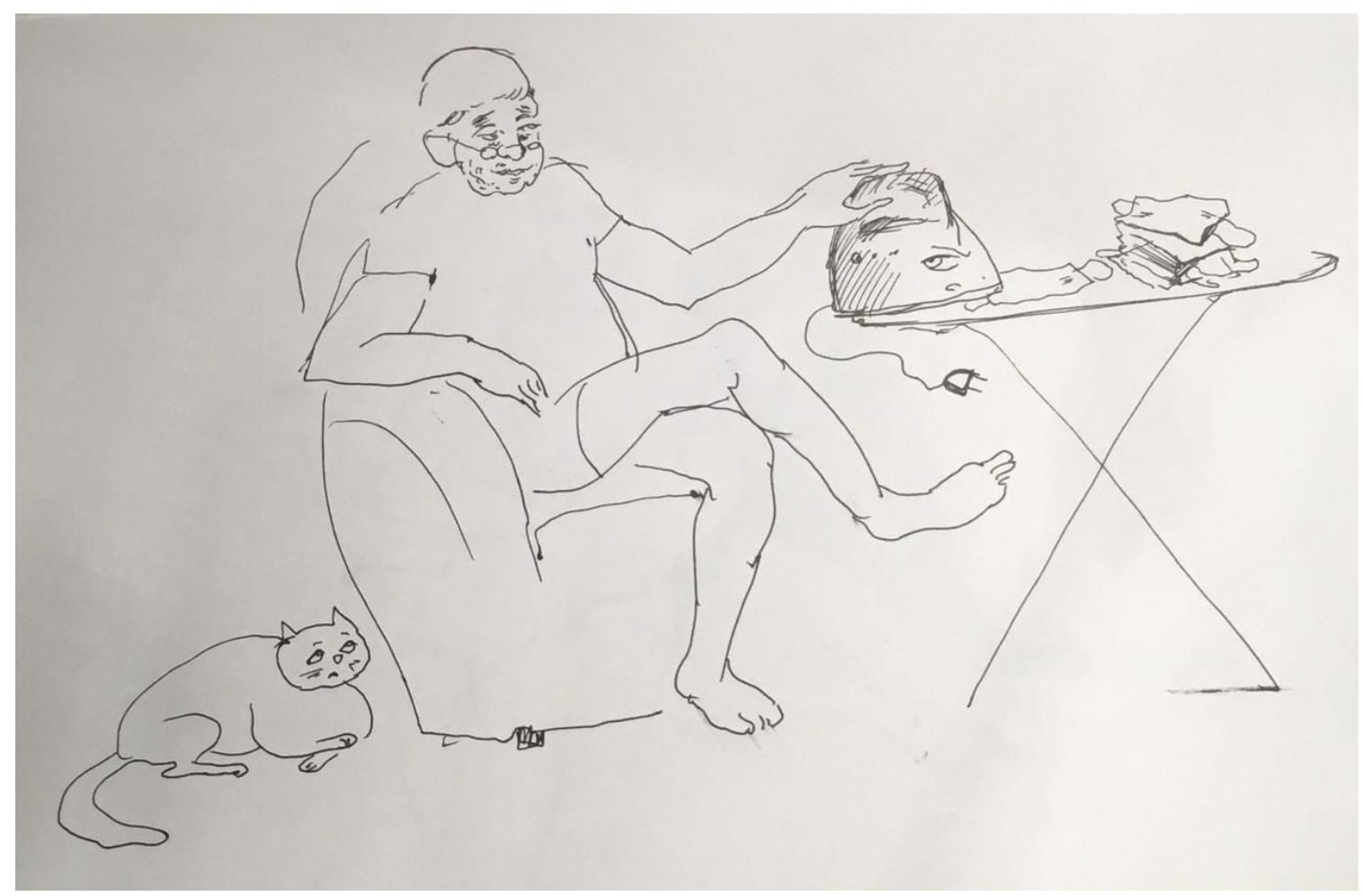

Рис. 9. Художник Spessiva

Fig. 9. Artist Spessiva

Часто сопоставляются прошлое и настоящее: «2019 год, выносишь пакет с бутылками: "Не, я не алкоголик, вы чё, у меня просто вечеринка была!" 2020 год, выносишь пакет с бутылками: "Не, у меня никакой вечеринки не было, я просто алкоголик!"»; «2000 год: к 2020 году появятся летающие машины. 2020 год: не летают даже самолёты»; «Раньше мы все жили в психиатрической больнице, а с 2020 года мы все живём в инфекционном отделении психиатрической больницы»; «2019 год: когда же мы будем хорошо жить? 2020 год: как же мы хорошо жили!»

Будущее в силу карнавальной специфики и терапевтической функции жанра рисуется неприглядным: «Говорят, что третья волна коронавируса 
наступит в марте. А можно сразу озвучить, сколько сезонов в этом б*** сериале?» В лучшем случае ожидается, что через некоторое время самой популярной косметической операцией сделается восстановление формы ушных раковин, оттопыренных от постоянного ношения маски, либо увеличится количество одиноких женщин: «2025 год. Маленькая девочка спрашивает свою маму: "Мам, а кто мой папа?" - "Не знаю, он в маске был"». В диалогическую форму облекаются многочисленные анекдоты, сюжет которых составляют рассказы родителей, бабушек и дедушек о том, как странно всё было до пандемии: бары, рестораны, парикмахерские, прогулки, рукопожатия. Образы людей будущего зловещи: комбинезоны химзащиты, скафандры, чипы и т. п.

\section{Шутки на политическую тему}

Юмор может привлекать внимание к общественным проблемам, способствовать эмоциональному вовлечению граждан в обсуждение насущных вопросов (Benacka, 2017). Л.Н. Столович отмечает важную особенность бытования анекдота, который «своим остроумием и комическим потенциалом... способен разъедать, разоблачать любой миф, в особенности навязываемый сверху» (2002, с. 54). По мнению китайского учёного С. Ли, подавляющая часть новых текстов в нашей стране - политического характера. «Многие исследователи отмечают, что анекдот как жанр был популярен в СССР как завуалированная форма протеста в тоталитарном государстве, однако в современном демократическом российском обществе проблематика и характер комического в анекдотах остаются прежними» (2019, с. 5), - указывает языковед.

В контексте обозначенного объекта исследования внесём ясность: рост числа заболевших, умерших вызывает недовольство в любой стране. Люди порицают неразумное управление государством, коррупцию элит, неправомерность ограничений, нехватку средств и ресурсов, невозможность противостоять кризису. К. Николс пишет, что потерявшие влияние в результате неспособности или нежелания контролировать распространение вируса политики спровоцировали серьёзную агрессию в Соединенных Штатах, Британии, Китае, Бразилии, это выразилось в распространении мемов, карикатур, статей (Nicholls, 2020, p. 284). В российских миниатюрах на ковидную тему политическая проблематика не является доминирующей, однако таких историй много. Жёсткие меры, на которые вынуждено идти правительство в экстремальной ситуации, часто вызывают протест, отторжение. Появляются подозрения в фальсификации статистики, распространении ложных данных. Анекдоты отражают эти опасения.

На первом этапе распространения заболевания речь ведётся об утаивании фактов: «Разработанный Минздравом способ подсчёта больных спас Россию от новой вспышки коронавируса»; «Никакого взрыва эпидемии коронавируса у нас нет и не будет. У нас только хлопки пневмонии»; «Судя по 
публикуемой статистике заболеваний коронавирусом, ближе к 1 июля у нас будут только выздоровевшие, а то и воскреснет даже несколько человек».

Традиционная для критиков тема - обличение коррупции. Например: «На войну с коронавирусом выделили большие деньги. А значит, война будет долгой и кровопролитной». В ряде текстов отражается негативное отношение к депутатам: «В Государственной Думе начали проводить по три дезинфекции в день. Но паразиты по-прежнему приходят на заседания». И шире - к государственным служащим: «Чтобы победить коронавирус, надо думать, как коронавирус!" - сказали чиновники. "Да вы уже и так хуже холеры”, - подумал народ».

Иронически комментируются решения о проведении парада Победы и голосования по поправкам в Конституцию: «Никогда ещё распространение инфекции не было таким парадным!»; «Режим самоизоляции и маски отменяются. Страна пошла на поправки».

Героями «ковидных» анекдотов становятся видные деятели: президент, министры, губернаторы, политики. В.В. Путин часто позиционируется в текстах как харизматичный лидер: «"Когда хоть эта пандемия закончится?!!” - "В нашей стране как Путин скажет, так и закончится...»; «В.В. Путин посетил Институт эпидемиологии и лично создал вакцину от коронавируса»; «В связи с ковидом и ростом цен на черноморские курорты Путин перенёс жару в Москву». В прошлом властные функции самодержца в представлении русского народа, прежде всего крестьянства, подвергались сакрализации, что обусловливало культ царской личности (Коновалова, 2007, с. 126). Как видно из приведённых выше примеров, следы проявления этого феномена можно до сих пор обнаружить в фольклоре, в том числе в миниатюрах с сатирической окраской.

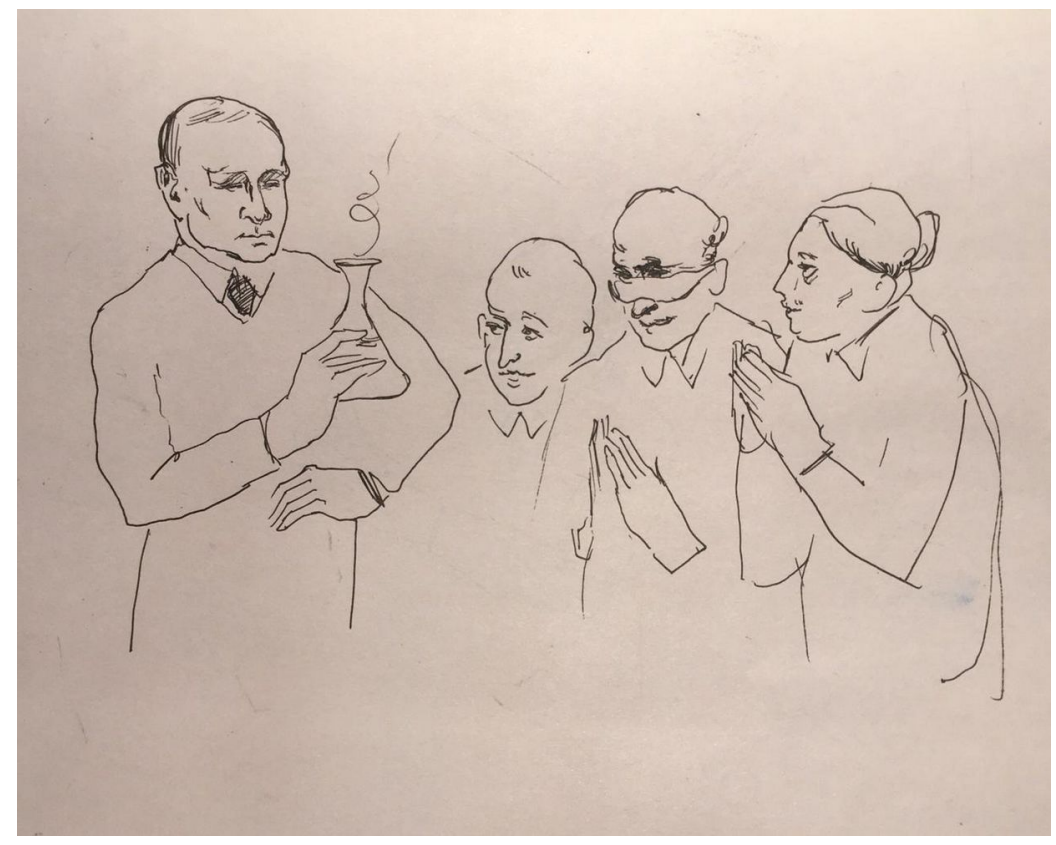

Рис. 10. Художник Spessiva

Fig. 10. Artist Spessiva 
Каламбур лежит в основе анекдота о болезни председателя правительства: «Премьер-министр Михаил Мишустин впервые за 100 дней работы показал положительный результат». Иронически обыгрывается фамилия государственного деятеля в следующем примере: «В связи с тем, что премьер Мишустин заразился коронавирусом, Путин приказал срочно разбудить Медведева».

В России уровень политической и общественной активности граждан сильно колеблется, он наиболее высок в крупных городах, прежде всего, в Москве. Это объясняет существование большого количества анекдотов про мэра столицы: «На приёме у психолога: “Доктор, меня бесят люди, я обожаю пустые улицы и города". - "Вы мэр Москвы?” - Да, так совпало"»; «Мэр Москвы Собянин призвал жителей столицы во время карантина брать пример с Ленина, который уже почти 100 лет не выходит из дома»;

- Сергей Семёнович, заболеваемость коронавирусом растёт!

- Срочно меняйте все бордюры на новые!

- Заменили, всё равно растёт!

- Меняйте всю плитку на новую!

- Заменили, не помогает!

- Что же это за зараза-то такая, ничего её не берёт!

Важная особенность анекдота - способность быстро реагировать на события. Благодаря цифровым технологиям скорость распространения шуток существенно возросла, появляется больше текстов, связанных со свежими новостями. Приведём примеры: «То, что Гейтс разрабатывает вакцину от коронавируса, это неплохо. Плохо, что эта вакцина будет регулярно требовать лицензию и своего обновления» (апрель 2020); «Голодающие без концертов артисты попросили у правительства талоны на мраморную говядину и осетра» (май 2020); «Насколько всё-таки Россия отстаёт от Америки! Трамп уже вылечился от коронавируса, а Путин ещё даже не заразился» (октябрь 2020); «"Посмотрел видео с Дзюбой и не понял, почему все так возмутились”. - “Да ты что, он же без маски был!"» (ноябрь 2020); «Из-за коронавируса COVID-19 отменили концерты Ольги Бузовой... Уже в который раз Природа встаёт на защиту людей» (декабрь 2020); «Цены на свёклу поднялись, потому что из-за ковида её стали сажать через 1,5 метра» (май 2021); «Согласно законам ЕС, вакциной может называться только та, которая произведена в регионе Вакцин, Франция. Все остальные вакцины - это игристый антидот» (июль 2021). Доказано, что значительность объёма имплицитной части текста определяет потенциал смехового эффекта (Чиркова, 1997, с. 13). «Новостные» варианты позволяют ограничиваться аллюзиями, прибегать к фигурам умолчания. По понятным причинам подавляющее большинство подобных текстов быстро перестают быть актуальными и забываются. 


\section{Антипрививочные настроения}

Важнейшими этапами борьбы с пандемией стали разработка антиковидной плазмы, кампания по масштабной вакцинации, рекомендации Минздрава по ревакцинации. Все эти шаги запечатлены в большом количестве анекдотов.

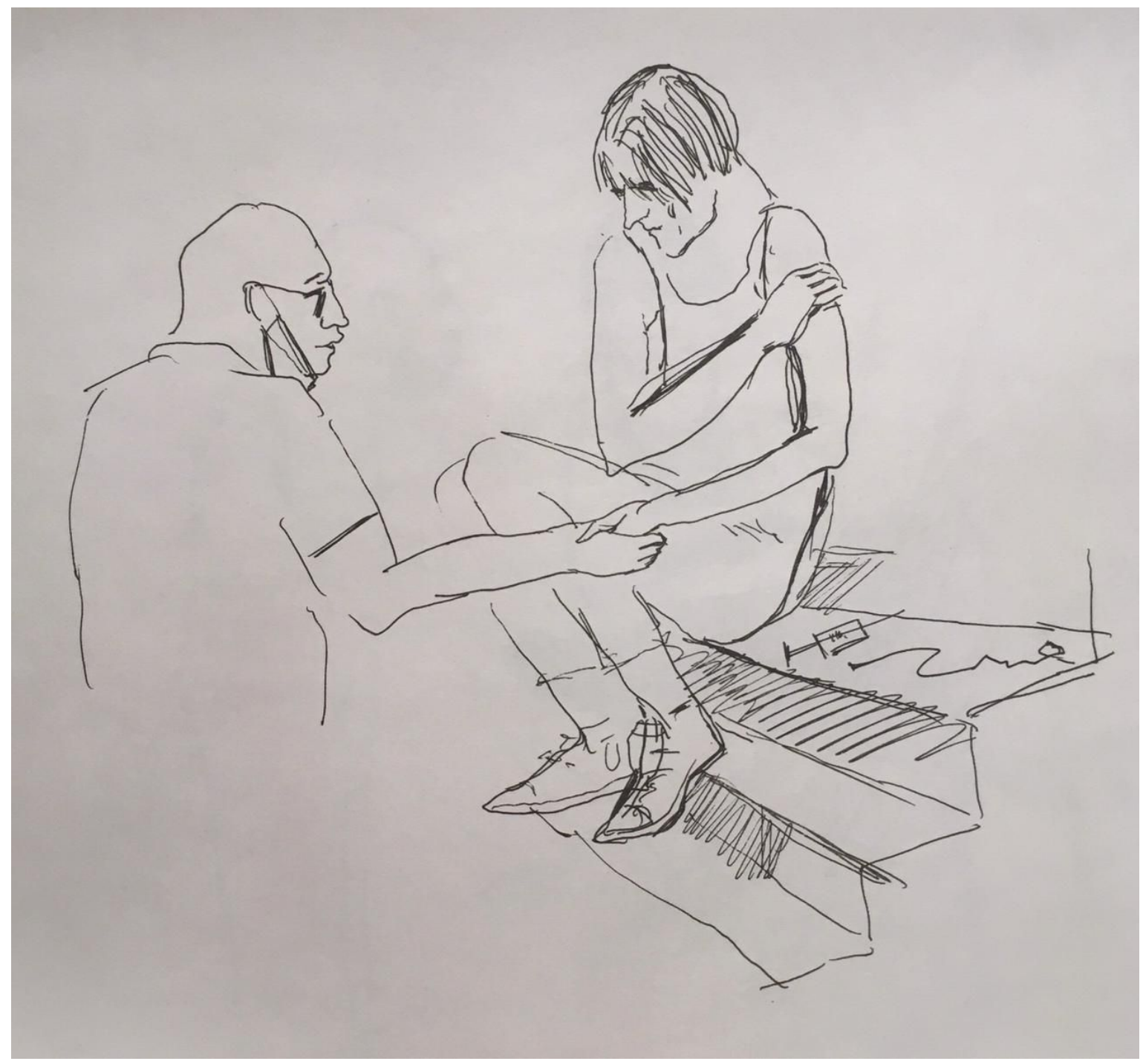

Рис. 11. Художник Spessiva

Fig. 11. Artist Spessiva

Процедура ввода препарата с антигенным материалом саркастически соотносится с внутривенным введением наркотических веществ: «Выхожу сейчас из квартиры, а там двое прямо на лестничной площадке вакцинируются. Уважуха»; «Добровольцы рассказали об ощущениях от российской вакцины против COVID-19: "Реально вставляет"». Карнавальное сознание стремится к фамильяризации, снижению, приземлению всего, что воспринимается как значимое и серьёзное во внекарнавальной жизни (Слышкин, 2000, с. 56). 
Поэтому сопоставление вещества, несущего спасение, со смесью, таящей смертельную угрозу, почти закономерно. Тем более что параллель вакцина / наркотик получает обоснование среди сторонников теории мета-заговора: по их мнению, внедрение вакцин направлено на установление системы тотального контроля, выработку зависимости, которая вынудит человечество постоянно платить за искусственный иммунитет.

Скептическое отношение к отечественной системе здравоохранения проявляет себя в анекдотах на тему плачевных последствий прививок: «В испытании новой российской вакцины приняли участие 10000 человек. По окончании испытаний все 5000 чувствуют себя хорошо. "Простите, а что ж остальные 5 000?" - "А они не прошли испытание”»; «Граждане, получившие оба компонента российской вакцины, могли посмотреть прямую линию с Путиным без телевизора»; «Сделал прививку - даже в лесу теперь Wi-Fi ловит». Критикуется пропагандистская деятельность: «О российской вакцине от коронавируса уже слагают легенды, сказки, тосты. Причём, лучше всего получаются сказки»; «"Российская вакцина от короновируса настолько эффективная, что тысячи моментально выздоровели, миллионы сбросили маски и ходят, ничего не боясь". - "И это ей ещё прививать не начали"»; «О существовании некоторых стран узнаю исключительно из новостей о том, что они зарегистрировали “Спутник V”».

Было бы ошибкой утверждать, что официальная политика государства в отношении прививок огульно осуждается. Встречаются тексты противоположной направленности: «Антипрививочники крайне возмущены отсутствием прививки от коронавируса, от которой они могли бы отказаться»; «Забавно наблюдать за тем, как люди, которые покупают себе чипсы по 30 рублей, возмущённо интересуются составом вакцины...»; «Не вакцинируйтесь ни в коем случае! Не мешайте естественному отбору!» Анекдот - одно из оружий информационной войны. Не удивительно, что среди прочих на просторах Интернета появляются тексты на тему необходимости лечения в больничных условиях, пользы от ношения масок и соблюдения карантинных мер, опасности фиктивной «кьюаризации» ${ }^{1}$. Во многих таких миниатюрах высмеиваются человеческие глупость, упрямство, доходящее до фанатизма. Например: «Шок! Позвонил друг, говорит, заразился. А ведь прививался от короны всего полмесяца назад! Правда, заразился триппером. Но что это меняет!»; «"А вакцина от КОВИД-19 опасна?" - "Конечно опасна! у меня друг сделал прививку, а через неделю умер. Машина сбила"». Важной жанровой особенностью анекдота является нарушение официальных табу (Душенко, 2000, с. 79) культурных, социальных, идеологических. Видимо, поэтому благонамеренные шутки в деперсонализированном сознании граждан укореняются с трудом.

По замечанию М.С. Петровского, анекдотическое творчество «прямо пропорционально количеству запретов и противоположно их смыслу» (1998,

1 Незаконного получения сертификата с QR-кодом. 
с. 16). Вследствие чего ужесточение мер, принимаемых российским правительством летом 2021 г. для максимального охвата населения вакцинацией, вызывает очередной поток острот. Вновь, как и в случае с карантином, отмечается проблема разделения населения страны: «Половина жителей России поддержали обязательную вакцинацию другой половины»; «Зафиксирован эмоциональный эффект вакцины Спутник V. Теперь вакцинированные люди ненавидят невакцинированных людей».

В ответ на летний указ о запрете для не имеющих QR-кодов либо данных ПЦР-тестов на посещение заведений общественного питания, концертов, спортивных мероприятий, заселение в гостиницы, кемпинги и т.п. появляются анекдоты о других ограничениях. Миниатюры предельно заостряют жизненные ситуации, причудливо сочетая правдоподобное и алогичное. Отказавшимся прививаться россиянам якобы грозятся включить в жару отопление, перестать платить зарплату; их не примут в тюрьмы, начнут расстреливать, мало того - не пустят в рай.

Переиначиваются новости о розыгрыше среди привившихся: «В Москве среди вакцинированных разыграют три деревни в Костромской области, вместе с населением»; «Среди прививающихся москвичей будет разыгран пост главного тренера сборной России по футболу»; «Среди вакцинировавшихся девушек будет разыгран жених из богатой семьи». Иронически констатируется восторженная поддержка планов по ревакцинации: «Миллионы россиян завалили Валентину Терешкову письмами с просьбой обнулить результаты вакцинации и провести новую вакцинацию, обязательную и платную».

Отражение в анекдотах находят сложности, возникшие у потенциальных клиентов после появления системы QR-кодов в кафе и ресторанах:

- Ваш QR-код?

- Bот.

- ПЦР тест?

- Вот.

- Тест на антитела?

- Вот он.

- Заявление на ревакцинацию?

- Вот. Копия.

- Талон на ревакцинацию?

- Вот, к заявлению приколот.

- Проходите. Что вам?

- Биг Мак и колу.

Немедленно следует креативная реакция и на снятие запрета: «Ну всё, QR-коды отменили. Расскажите, как теперь сделать девакцинацию?»

Как показывает произведённый анализ, в «ковидных» анекдотах поднимаются практически все волнующие людей проблемы: ограничение прав и свобод, финансовые трудности, усталость от неопределённости, угроза здоровью и жизни. В этом смысле жанр универсален. Шутки не только выполняют защитную, компенсаторную функции. Они воспроизводят общественные, 
национальные стереотипы, позволяют в тяжёлой ситуации пандемии включиться в социальную действительность.

\section{Характерные мотивы и образы}

Tема COVID-19 далеко не всегда поднимается отдельно. Многие бродячие сюжеты просто переносятся в новую ситуацию. Так, неизменным успехом пользуются шутки о взаимоотношениях мужчин и женщин. Обыгрываются истории о дистанционных свиданиях, «безопасном» сексе в масках и перчатках, самоизоляции с двумя «крошками в постели» и т.п.

Как массовый фольклорный жанр анекдот воплощает в себе гендерные стереотипы. Поведение полов значительно различается. Г.Г. Слышкин так характеризует типичные роли: «Средний мужчина - это лицо, приверженное к алкоголизму, стремящееся уйти из дома. И в то же время женщина это некое существо в бигуди, довольно скупое, довольно скандальное, которое стремится его удержать в этом семейном кругу. Собственно, основная функция женщины в семейных анекдотах - это именно момент удержания... И это урбанистический образ семьи в русской культуре» (Ляленкова, 2006).

В «ковидных» анекдотах персонажи жалуются на закрытые стадионы и бары, на отсутствие автомобильных пробок, которыми можно объяснить опоздания, на необходимость постоянно находиться вместе с супругой («Как же много мужчин не смогут провести этот месяц со своими любимыми! К сожалению, им придётся остаться дома со своими жёнами»). Один из устойчивых мотивов историй о семейной жизни - лень мужчины в быту: «Любовь это когда отдаёшь жене последнюю маску, чтобы она сходила в магазин тебе за пивом»; «Муж стоит, смотрит в окно, не отрываясь на другие дела. К нему подходит жена и спрашивает: “Ты уже два часа пялишься в окно! Лучше бы помог купленную гречку по полкам расфасовать!" - "Отстань, женщина, я гуляю"». Мужчины больше болеют, потому что касаются дверных ручек, чтобы открыть женщинам дверь. Женщины чаще заражают, так как способны собраться в магазин в субфебрильном состоянии: «Вы когда-нибудь видели, чтобы мужчина с температурой $37^{\circ} \mathrm{C}$ куда-то выходил из дома?»

По мнению исследователей, преобладание у мужчин абстрактного типа мышления предопределяет их активную роль в сочинении анекдотов. Поэтому большинство миниатюр реализуют мужскую картину мира, в которой слабому полу приходится несладко: женщина лишается подарка из-за пущенного слуха о заразности цветов и айфонов, несколько дней стучится в дверь, потому что благоверный усердно соблюдает карантин и не пускает её в квартиру; вынуждена продолжать носить марлевую повязку, несмотря на отмену масочного режима, дабы не показывать своё страшное лицо («...полгода жена в наморднике, это не так уж и плохо»). Развод чаще позиционируется как счастливое освобождение: 
«Продолжают поступать тревожные сообщения о побочных эффектах вакцинации. На этот раз беда произошла с 40-летней женщиной-врачом, от которой после вакцинации ушёл муж, тоже врач. Ушёл к 25-летней непривитой медсестре. Узнав об этом событии, сантехник Михалыч вакцинировался трижды, но жена так и не ушла».

Достаточно много в «ковидной» группе шуток про тёщу. Зять покупает родственнице путёвку в Милан, «в связи с распространением коронавируса» настрого запрещает приезжать в гости, отправляет на фальшивую вакцинацию. Фотография жены с тёщей заменяет цифровой документ: сотрудник ДПС беспрепятственно пропускает мужа к любовнице.

Существенный пласт анекдотов ориентирован на юмор «ниже пояса». Оппозиция нормативный / ненормативный всегда актуальна для форм комического. С точки зрения прагматики, состояние фрустрации можно преодолеть путём нарушения запретов, особенно если это нарушение связано с категорией телесности. Тревога, агрессия, депрессия, развивающиеся на фоне пандемии, вызывают потребность в снятии нервно-психологического напряжения. В связи с чем среди миниатюр, посвящённых COVID-19, много шуток фривольного характера. Демонстративный эротизм, как правило, присущ героям-мужчинам: «"Лучшее лекарство от коронавируса - это секс с незнакомцем в белом халате!" - "Простите, а вы точно терапевт?"»; «"Доктор, а это точно была вакцинация?" - "Конечно!" - ответил доктор, застёгивая ширинку»; «Николай, убедив всех, что антитела передаются половым путём, вакцинировал весь посёлок. А некоторых - и по два раза. С тех пор его называют Коля Спутник».

Отдельная тема - любовь российского мужчины к спиртному. Алкоголь представляется в анекдотах как средство профилактики, «внутренней» дезинфекции, как национальная вакцина ${ }^{1}$ (на этот счёт существует огромное количество вариантов), доступный «самоизолятор» ${ }^{2}$. При этом подчёркивается «тонкая семантическая разница между депрессивным экзистенциализмом карантинного запоя и феерией беззаботного пьянства».

На заявления Т.А. Голиковой, А.Ю. Поповой о необходимости ограничения употребления спиртного на период вакцинации от лица мужчин почти мгновенно даётся симметричный ответ: «Вторую неделю в топе поиска Яндекса один и тот же вопрос: как напиться на 42 дня вперёд?»; «На Уралвагонзаводе началась ловля трезвых слесарей для вакцинации. Пока не поймали ни одного»; «"Сначала Голикова говорила, что для вакцинации надо 42 дня не пить, а сейчас сказала, что достаточно 3 дня до и 3 дня после не пить. Пойдёшь вакцинироваться?" - "Нет, подожду, когда наливать стопочку за здоровье начнут"».

1 Отметим, что на самом деле такие шутки распространяются на международном уровне, популярны, например, в Германии (Тюкина, 2021, с. 150), Голландии (Meder, 2020, p. 137), Польше (Станкевич, 2020, с. 2) и др.

2 Средство, позволяющее пережить вынужденную самоизоляцию. 
Трагические события, связанные с пандемией, вынуждают людей пытаться минимизировать отрицательные переживания. Ещё одним способом получения позитивных эмоций становится актуализация идеи национальной идентичности, общности (Копылкова, 2006, с. 7). Выдвинуть их на передний план помогает анекдот. Транслируется мысль о непобедимости русского народа, верного обычаям и привыкшего к трудностям: «Кто в детстве мочил манту, тому коронавирус не страшен»; «Прошло то время, когда мы стирали одноразовые пакеты! Пришло то время, когда мы стираем одноразовые маски... Традициям верны!»; «Едешь утром в трамвае, смотришь на людей без масок и понимаешь, что русская рулетка так и осталась нашей самой любимой игрой». Болезнь отступает перед мощью страны: «При пересечении границы России коронавирус теряет свои патологические свойства и становится обычным ОРВИ».

Национальное самоопределение происходит также за счёт изображения «странных Чужих» - с использованием популярных этностереотипов. Отчётливо фиксируется культурное различие «своего» и «чужого». Н. Миццо замечает: когда мы вместе смеёмся, то сигнализируем себе и другим о сходстве, которое является основой для идентификации (Miczo, 2021). Приведём примеры «рассказов об инородцах»:

«Когда завершится пандемия, американцы обязательно снимут фильм про то, как они спасли весь мир от коронавируса».

«Чехия прекращает разработку своей вакцины от коронавируса. У них всё время получается пиво».

«Узбекские учёные пытались создать вакцину от коронавируса, но всякий раз у них получался плов».

«Власти Туркменистана запретили слово “коронавирус". Теперь местные врачи ставят заражённым диагноз "Шайтан 19"».

«Эстония объявила карантин из-за свиного гриппа».

«В Одессе с коронавирусом просто договорились. Он даже остался немножко должен».

Нужно отметить, что шутки про евреев занимают особое место в этом ряду - и по степени распространённости, и в плане формы. Как справедливо отмечают А.Д. и Е.Я. Шмелёвы, «в таких анекдотах мы имеем дело не с образом еврея в русском анекдоте, а с образным строем еврейского анекдота» $(2014$, c. 218). Специфический национальный колорит шуткам придают речь персонажей, интонационно близкая к одесскому говору, использование героями непрямых способов выражения мысли, особенности поведения и др. См.: «Моня, сынок, если ты таки собираешься жениться, то сейчас самое подходящее время - мы можем никого не приглашать на твою свадьбу!»; «Объявление в израильском кафе: "Всем, кто жалуется на то, что вкус шавермы и фалафеля изменился: это потому что работники теперь моют руки. С Божьей помощью всё скоро вернётся на свои места"»; «"Моня, ви таки маски ещё 
шьёте?" - "Ви што, Сёма? Это ж вчерашний день! Вакцину варим!" - "Моня, ви всё ещё варите мне вакцину?" - "Вчерашний день, Сёма! Справки о мед. отводе продаём"».

Устойчивый тип юмористических историй - анекдоты о людях разных национальностей, позволяющие сопоставить действия / ответы персонажей:

Победило человечество коронавирус и на радостях проводит всемирный конкурс - кто сильнее всех разленился на самоизоляции. В финал вышли представители Германии, США, Франции и России. Задание в финале было таким: написать, почему ты самый ленивый.

Четвёртое место занял немец, он написал: «До карантина я разослал резюме в разные компании. Пришло очень выгодное предложение, но я из-за лени отказался».

Третье место - американец: «Для получения крупной компенсации нужно было заполнить бланк. Заполнять было лень, и я ничего не получил».

Второе место - француз, написавший, что любовница и жена предложили ему заняться сексом втроём, но он отказался. Просто было лень.

Первое место русский - он сдал чистый лист.

Как видим, именно русский в отечественных анекдотах поступает самым неожиданным образом; описание его действий составляет пуант.

На манифестацию идеи национальной идентичности отчасти работают широко известные сюжеты, преподнесённые в обновлённой форме: «Тридцать лет и три года лежал Илья Муромец на печи. Такого подвига самоизоляции ещё не знала Русь»; «Мюллер: “Штирлиц, а почему сейчас, когда вся Германия заражена коронавирусом и наши сотрудники скупают туалетную бумагу, вы покупаете только гречку?"»; «Первый, кто правильно принимал душ, придя с улицы, был Ипполит в “Иронии судьбы"».

Впрочем, активно используются и зарубежные претексты, имеющие статус культурного фетиша: Отелло бесконтактно душит Дездемону; находящийся на карантине Робинзон Крузо гонит Пятницу с острова; собака Баскервилей издаёт душераздирающий вой, когда её в 60-й раз ведут на прогулку. Как пишет О.А. Чиркова, популярные имена в анекдоте - «коды, в которых свёрнуты целые концепции личности. Имя-образ несёт максимум информации» (1997, с. 11-12). Сходный механизм работает, когда в анекдоте упоминаются медийные лица. Вот несколько примеров таких миниатюр: «По окончании пандемии Церетели обещал перед зданием мэрии Москвы установить ЦарьМаску»; «Коронавирус, подбиравшийся к Бабкиной, был затоптан хороводом»; «Любопытно, будет ли коронавирус извиняться перед Кадыровым?». Имена отсылают слушателя / читателя к прецедентной ситуации, за счёт чего достигаются увеличение объёма подтекста и двуплановость восприятия. 


\section{Поэтика}

Изобразительно-выразительные средства и приёмы анекдотов про COVID-19 очень разнообразны, что видно из текстов, процитированных выше. Сложно выделить какие-то характеристичные особенности.

Пародируются типичные ситуации. Например, телефонный мошенник пытается перевести антитела на свой иммунитет: «Добрый день. Это служба безопасности Госуслуг. Кто-то пытался привиться за Вас. Продиктуйте четыре последние цифры из Вашего QR-кода». В следующем примере переиначиваются реалии пляжного бизнеса: «Роспотребнадзор не рекомендует прививаться на пляже - вакцина может быть несвежей. Лучше дойти до ближайшего прививочного киоска. Да и дешевле выйдет».

Некоторые шутки являют собой переделки ранее существовавших. Например: «"Папа, а давай слоники ещё побегают”. - “Дима, ты разве не знаешь, что в связи с этим коронавирусом, прапорщик Нечипоренко списал и продал все противогазы?"» (в исходном варианте дочь уговаривает отца, и тот, сдавшись, отдаёт команду «Рота! Одеть противогазы!»); «Кто за ПЦР девушки платит, тот её и танцует» (первоначально «Кто девушку ужинает, тот её и танцует»).

Инверсии превращают то или иное положение в свою противоположность: «"Понаехали тут, Россия не резиновая!" - с такими словами жители провинции встречают ломанувшихся во все стороны москвичей»; «В банк вошли трое без масок. Охрана, клерки и клиенты сразу всё поняли, закутали лица и легли на пол».

Особую выразительность придаёт высказыванию параллелизм. Например, когда в один ряд поставлены два очень похожих предложения, противоположных по смыслу: «В детстве я не выходил на улицу, потому что был наказан, теперь не выхожу на улицу, потому что буду наказан».

Комический эффект достигается в результате сопоставления несопоставимых понятий: «Во время эпидемии коронавируса резко поднялась цена на гречку, чеснок и имбирь и упала на футболистов и хоккеистов».

На лексическом уровне примерно тот же эффект производит подмена слов в устойчивых выражениях: «В это трудное время нам как никогда надо держаться порознь!»; «"Дурной премьер заразителен”, - подумал Путин и отправил Мишустина на больничный».

Обыгрывается иное значение термина: «Уважаемые покупатели "Пятёрочки", просьба соблюдать социальную дистанцию от покупателей ELENA FURS и "Бриллиантов Якутии". Будьте здоровы!» ${ }^{1}$ Либо иное значение слова: «"Выходи за меня!" - “Сейчас нельзя никуда выходить!"». Переосмысливаются фразеологизмы: «Для чего нужны маски? Чтобы молчать в тряпочку»².

1 В этом примере содержится отсылка к исходному смыслу словосочетания, подразумеваемому его автором - Г. Зиммелем: отчуждённость социальных групп.

2 Наблюдаем любопытный пример восстановления утраченного смысла: первоначально выражение было связано с обычаем затыкать пленным рот кляпом. 
Типичным для комических текстов является приём сопоставления полных лексических омонимов: «"Здравствуйте, есть свободный столик?” “Добрый день. Вы одна или со Спутником?"». Подбора созвучных слов: «По правилам хорошего тона теперь при встрече надо говорить не "Привет!", а “Привит!" Спрашивать не “Как дела?", а “Как антитела?"». И соотнесения смыслов одноморфемных коррелятов: «Если самоизоляция не поможет, введут самоликвидацию».

Пожалуй, специфическим приёмом, характерным именно для «ковидных» анекдотов, можно назвать антропоморфизацию образа вируса. Он не просто одушевляется, но наделяется человеческими манерами, привычками, пороками:

«Встречаются два коронавируса. "Я вчера такую красотку в постель уложил!" мечтательно говорит один. Второй грустно отвечает: "А мне не везёт. Всё старухи да старухи попадаются"».

«Когда смолк звон 11-го удара стенных часов, коронавирус надел непромокаемый плащ, повязал тёплый осенний шарф, надел сапоги и вышел на охоту. Он точно знал, что его ждут в ночных ресторанах и клубах».

«"Но ведь обещали, что коронавирус погибает на солнце и боится жары!” -

“Так это индийский штамм, под солнцем он умеет прятаться, а от страха вообще танцует"».

Изображение вируса в качестве независимого существа, способного проявлять симпатию, наряжаться и танцевать, безусловно, вызывает смех. Однако значим тот факт, что в старину болезни представлялись в человеческом образе (правда, женском), а эпидемию воспринимали как нарушение границ между этим и иным мирами. Жанр анекдота, в котором большинство действующих лиц мужчины, превращает вирус в «мужика». Но по характеру умозаключений массовое сознание уподобляется логике архаического мифа.

\section{Заключение}

В конце прошлого века А. Левинсон сравнил анекдот с вирусом (1999, c. 377). И тот и другой могут жить, только непрерывно меняя хозяина. После того, как коллектив / организм «переболели», восприимчивость утрачивается - до тех пор, пока он, преображённый, не появляется вновь. Теперь вирусными называются ролики, которые бескорыстно распространяются в Интернете рядовыми пользователями.

Развитие цифровых технологий не просто опять делает жанр анекдота популярным, но возвращает его в стихию народной речи. Снова становится возможным вести непосредственную синхронную коммуникацию, быстро обмениваться неофициальной информацией, в том числе точечно, реагировать на конкретную тему, импровизировать, подключать фонационные и кинетические средства выразительности, учитывать реакцию слушателя / читателя / зрителя. Старый жанр обретает новую форму, появляются опции использо- 
вания графических невербальных средств, виртуальных элементов; представляется шанс заинтересовать многомилионную аудиторию.

В ситуации пандемии дистанционный способ общения порой оказывается единственным. Возникновение большого количества «ковидных» шуток часто объясняют высвобождением времени: в связи с вынужденной изоляцией у людей раскрываются творческие способности. Это далеко не единственный фактор. Общество стремится к объединению, пусть даже технологически спроектированному.

Проблематика актуальных в 2020-2021 гг. анекдотов демонстрирует, что массовое сознание реагирует на все заметные события, связанные с эпидемией. Панический страх перед заражением, пугающая статистика, изучение непривычных симптомов болезни, ажиотажный спрос на ряд товаров первой необходимости, средств диагностики и лечения заболевания, неконкурентные закупки и другие виды коррупции, формы профилактики, запреты на передвижение, локдаун, дистанционная работа (учёба), разработка иммунобиологических препаратов, новые штаммы, кампания по масштабной вакцинации, ревакцинация, система QR-кодов и их частичная отмена... Высокая скорость распространения текстов увеличивает количество «новостных» шуток, основанных на предоставленной оперативной информации.

Многие анекдоты строятся на переиначивании привычных сюжетов: супружеская измена, война с тёщей, любовь к алкоголю, национальные стереотипы и т.д. Активно используются алогизм, абсурд. Типичны варианты инверсирования: хозяева / их питомцы, вакцина / наркотик, маска / трусы. Напряжение, страх подталкивают людей к выходу за пределы допустимых норм. Особенно значимыми становятся коммуникативная, компенсаторная, психотерапевтическая, гармонизирующая функции анекдота. Иногда тексты конструируются намеренно - как инструмент воздействия на общественное мнение. Чаще миниатюры появляются спонтанно. Освобождает смех или примиряет - вопрос спорный.

\section{Список литературы}

Benacka, E. (2017). Rhetoric, Humor, and the Public Sphere: From Socrates to Stephen Colbert. Lanham, MD: Lexington Books.

Bischetti, L., Canal, P., \& Bambini, V. (2021). Funny but aversive: A large-scale survey of the emotional response to Covid-19 humor in the Italian population during the lockdown. Lingua, 249. doi: 10.1016/j.lingua.2020.102963

Cancelas-Ouviña, L.-P. (2021). Humor in Times of COVID-19 in Spain: Viewing Coronavirus Through Memes Disseminated via WhatsApp. Frontiers in Psychology, 12. doi: 10.3389/fpsyg.2021.611788

Chłopicki, W., \& Brzozowska, D. (2021). Sophisticated humor against COVID-19: The Polish case. Humor: International Journal of Humor Research, 34(2), 201-227. doi: 10.1515/humor-2021-0015 
Dynel, M. (2021). COVID-19 memes going viral: On the multiple multimodal voices behind face masks. Discourse E Society, 32(2), 175-195. doi: 10.1177/0957926520970385

Felecan, D., \& Felecan, O. (2020). Conținuturi implicite în bancurile generate de pandemia Covid-19: Repere teoretice. Philologica Jassyensia, XVI(2), 265-271.

Hussein, A. T., \& Aljamili, L. N. (2020). COVID-19 humor in Jordanian social media: A socio-semiotic approach. Heliyon, 6(12). doi: 10.1016/j.heliyon.2020.e05696

Kuipers, G. (2002). Media culture and Internet disaster jokes: Bin Laden and the attack on the World Trade Center. European Journal of Cultural Studies, 5(4), 450-470. doi: $10.1177 / 1364942002005004296$

Meder, T. (2021). Online Coping with the First Wave: Covid Humor and Rumor on Dutch Social Media (March - July 2020). Folklore: Electronic Journal of Folklore, 82, 135-158. doi: 10.7592/ FEJF2021.82.meder

Miczo, N. (2021). The ethics of news media reporting on coronavirus humor. Humor: International Journal of Humor Research, 34(2), 305-327. doi: 10.1515/humor-2021-0011

Miller, J., \& Weinert, R. (1998). Spontaneous spoken language: Syntax and discourse. Oxford: Oxford University Press on Demand.

Nicholls, C. (2020). Online Humour, Cartoons, Videos, Memes, Jokes and Laughter in the Epoch of the Coronavirus. Text Matters: A Journal of Literature, Theory and Culture, (10), 274-318. doi: 10.18778/2083-2931.10.17

Olah, A. R., \& Ford, T. E. (2021). Humor styles predict emotional and behavioral responses to COVID-19. Humor: International Journal of Humor Research, 34(2), 177-199. doi: 10.1515/humor-2021-0009

Outley, C., Bowen, S., \& Pinckney, H. (2021). Laughing While Black: Resistance, Coping and the Use of Humor as a Pandemic Pastime among Blacks. Leisure Sciences, 43(1-2), 305-314. doi: 10.1080/01490400.2020.1774449

Saricali, M., Satici, S. A., Satici, B., Gocet-Tekin, E., \& Griffiths, M. D. (2020). Fear of COVID-19, Mindfulness, Humor, and Hopelessness: A Multiple Mediation Analysis. International Journal of Mental Health and Addiction. doi: 10.1007/s11469-020-00419-5

Shepherd, J. (2014, March 16). Why the internet loves cats - not dogs. The Guardian. Retrieved from https://www.theguardian.com/lifeandstyle/2014/mar/16/why-internet-loves-cats-notdogs

Александрова, Е. М. (2008). Жанр анекдота: Проблемы перевода (на материале русских и франиузских анекдотов). Орехово-Зуево: Московский государственный областной педагогический институт.

Ахметова, А. Р. (2020). «Шутка смешная, ситуация страшная»: Вирусные мемы о коронавирусе. Наука без грании: синергия теорий, методов и практик: материалы Международной научной конференщии, 111-115. Москва: Московский государственный лингвистический университет.

Бахтин, М. М. (1990). Творчество Франсуа Рабле и народная культура средневековъя и Ренессанса. Москва: Художественная литература.

Душенко, К. В. (2000). «Право на анекдот». Современный анекдот как социокультурный феномен. Человек: образ и сущность, (1), 75.

Земская, Е. А., Китайгородская, М. В., \& Ширяев, Е. Н. (1981). Русская разговорная речъ: Общие вопросы. Словообразование. Синтаксис. Москва: Наука. 
Карасик, В. И. (1997). Анекдот как предмет лингвистического изучения. Жанры Речи, (1), 144-153.

Каспэ, И. (2000). Кривое антизеркало.«Советский» и «постсоветский» анекдот: Проблемы жанровой трансформации. Новое литературное обозрение, (43), 327-334.

Коновалова, Н. А. (2007). Образ самодержавия в представлениях русского крестьянства по фольклорным материалам. Вестник Омского Университета, (4), 121-126.

Копылкова, Е. А. (2006). Анекдот как средство переживания национальной идентичности (на материале анализа еврейских анекдотов) (Диссертация). Москва.

Курганов, Е. (1997). Анекдот как жанр. Санкт-Петербург: Гуманитарное агентство.

Левинсон, А. (1999). Несколько замечаний по социологии анекдота в связи с новыми книгами об этническом и политическом юморе. Новое литературное обозрение, (37), 369-381.

Ли, С. (2019). Актуальные прецедентные феномены в современном русском анекдоте. Universum: филология и искусствоведение, (9), 4-8.

Ляленкова, Т. (2006, апрель 16). Мужчина и женщина. Мужской и женский анекдот. Радио Свобода. Извлечено от https://www.svoboda.org/a/138171.html

Мусийчук, М. В., \& Мусийчук, С. В. (2020). Юмор как эффективная стратегия совладания на самоизоляции в период пандемии коронавируса. Мир науки. Педагогика и психология, 8(5). Извлечено от https://mir-nauki.com/PDF/51PDMN520.pdf

Пельтцер, А. П. (1899). Происхождение анекдотов. Сборник Харьковского Историко-филологического общества, 11.

Петровский, М. С. (1998). Новый анекдот знаешь? Книюное обозрение, (27), 16-17.

Пропп, В. Я. (1984). Русская сказка. Ленинград: Издательство Лгу.

Пропп, В. Я. (1999). Проблемы комизма и смеха. Ритуальный смех в фольклоре (по поводу сказки о Несмеяне). Москва: Лабиринт.

Рашкофф, Д. (2003). Медиа Вирус! Как поп-культура тайно воздействует на ваше сознание. Москва: Ультра-культура.

Сиротинина, О. Б. (1974). Современная разговорная речь и ее особенности. Москва: Просвещение.

Слышкин, Г. Г. (2000). От текста к символу: Лингвокультурные концепты прещедентных текстов в сознании и дискурсе. Москва: Academia.

Станкевич, П. А. (2020). Юмор спасет мир: Интернет-мемы как реакция общества на мировую пандемию. Science in a Megapolis, (8), 2.

Столович, Л. Н. (2002). Анекдот и миф. В Анекдот как феномен культуры (сс. 46-53). Санкт-Петербург: Санкт-Петербургское философское общество.

Топоров, В. Н., \& Иванов, В. В. (1974). Исследования в области славянских древностей: Лексические и фразеологические вопросы реконструкции текстов. Москва: Наука.

Тюкина, Л. А. (2021). Юмористический диалогический дискурс: Анекдоты в эпоху COVID-19. Казанская наука, (3), 148-151.

Уханова, М. А. (2020). Анекдоты в цифровой среде (лингвокогнитивный анализ анекдотов в сети). Когнитивные исследования языка, (3), 483-488.

Чиркова, О. А. (1997). Поэтика современного народного анекдота (Диссертация). Москва. 
Шмелева, Е. Я., \& Шмелев, А. Д. (2002). Русский анекдот: Текст и речевой жанр [Текст]. Москва: Языки славянской культуры.

Шмелёва, Е. Я., \& Шмелёв, А. Д. (2014). Этнические стереотипы в русских анекдотах. Отечественные записки, (4), 167-177.

\section{References}

Akhmetova, A. R. (2020). "The joke is funny, the situation is terrible": viral memes about the coronavirus. Science without Borders: Synergy of Theories, Methods and Practices: Proceedings of the International Scientific Conference, 111-115. Moscow: Moscow State Linguistic University. (In Russian).

Alexandrova, E. M. (2008). Anecdote genre: translation problems (based on Russian and French anecdotes). Orekhovo-Zuevo: Moscow State Regional Pedagogical Institute. (In Russian).

Bakhtin, M. M. (1990). The Work of Francois Rabelais and the Folk Culture of the Middle Ages and the Renaissance. Moscow: Khudozhestvennaya Literatura. (In Russian).

Benacka, E. (2017). Rhetoric, Humor, and the Public Sphere: From Socrates to Stephen Colbert. Lanham, MD: Lexington Books.

Bischetti, L., Canal, P., \& Bambini, V. (2021). Funny but aversive: A large-scale survey of the emotional response to Covid-19 humor in the Italian population during the lockdown. Lingua, 249. doi: 10.1016/j.lingua.2020.102963

Cancelas-Ouviña, L.-P. (2021). Humor in Times of COVID-19 in Spain: Viewing Coronavirus Through Memes Disseminated via WhatsApp. Frontiers in Psychology, 12. doi: 10.3389/fpsyg.2021.611788

Chirkova, O. A. (1997). Poetics of a modern folk joke (PhD Thesis). Moscow. (In Russian).

Chłopicki, W., \& Brzozowska, D. (2021). Sophisticated humor against COVID-19: The Polish case. Humor: International Journal of Humor Research, 34(2), 201-227. doi: 10.1515/humor-2021-0015

Dushenko, K. V. (2000). "The right to a joke." A modern anecdote as a sociocultural phenomenon. Human: Image and Essence, (1), 75. (In Russian).

Dynel, M. (2021). COVID-19 memes going viral: On the multiple multimodal voices behind face masks. Discourse E Society, 32(2), 175-195. doi: 10.1177/0957926520970385

Felecan, D., \& Felecan, O. (2020). Conținuturi implicite în bancurile generate de pandemia Covid-19: Repere teoretice. Philologica Jassyensia, XVI(2), 265-271.

Hussein, A. T., \& Aljamili, L. N. (2020). COVID-19 humor in Jordanian social media: A socio-semiotic approach. Heliyon, 6(12). doi: 10.1016/j.heliyon.2020.e05696

Karasik, V. I. (1997). Anecdote as a subject of linguistic study. Genres of speech, (1), 144-153. (In Russian).

Kaspe, I. (2000). Curve anti-mirror. "Soviet" and "post-Soviet" anecdote: problems of genre transformation. New Literary Review, (43), 327-334. (In Russian).

Konovalova, N. A. (2007). The image of autocracy in the ideas of the Russian peasantry based on folklore materials. Omsk University Bulletin, (4), 121-126. (In Russian).

Kopylkova, E. A. (2006). Anecdote as a means of experiencing national identity (based on the analysis of Jewish anecdotes) (Doctoral Dissertation). Moscow. (In Russian). 
Kuipers, G. (2002). Media culture and Internet disaster jokes: Bin Laden and the attack on the World Trade Center. European Journal of Cultural Studies, 5(4), 450-470. doi: 10.1177/1364942002005004296

Kurganov, E. (1997). Anecdote as a genre. St. Petersburg: Humanitarian Agency "Academic Project". (In Russian).

Levinson, A. (1999). Actual precedent phenomena in the modern Russian jokes. New Literary Review, (37), 369-381. (In Russian).

Li, Xia. (2019). Actual precedent phenomena in the modern Russian jokes. Universum: philology and art history, (9), 4-8. (In Russian).

Lyalenkova, T. (2006, April 16). Man and woman. Male and female anecdote. Radio Liberty. Retrieved from https://www.svoboda.org/a/138171.html (In Russian).

Meder, T. (2021). Online Coping with the First Wave: Covid Humor and Rumor on Dutch Social Media (March - July 2020). Folklore: Electronic Journal of Folklore, 82, 135-158. doi: 10.7592/ FEJF2021.82.meder

Miczo, N. (2021). The ethics of news media reporting on coronavirus humor. Humor: International Journal of Humor Research, 34(2), 305-327. doi: 10.1515/humor-2021-0011

Miller, J., \& Weinert, R. (1998). Spontaneous spoken language: Syntax and discourse. Oxford: Oxford University Press on Demand.

Musiychuk, M. V. \& Musiychuk, S. V. (2020). Humor as an effective coping strategy for self-isolation during the coronavirus pandemic. The world of science. Pedagogy and Psychology, 8(5). Retrieved from https://mir-nauki.com/PDF/51PDMN520.pdf (In Russian).

Nicholls, C. (2020). Online Humour, Cartoons, Videos, Memes, Jokes and Laughter in the Epoch of the Coronavirus. Text Matters: A Journal of Literature, Theory and Culture, (10), 274-318. doi: 10.18778/2083-2931.10.17

Olah, A. R., \& Ford, T. E. (2021). Humor styles predict emotional and behavioral responses to COVID-19. Humor: International Journal of Humor Research, 34(2), 177-199. doi: 10.1515/humor-2021-0009

Outley, C., Bowen, S., \& Pinckney, H. (2021). Laughing While Black: Resistance, Coping and the Use of Humor as a Pandemic Pastime among Blacks. Leisure Sciences, 43(1-2), 305-314. doi: 10.1080/01490400.2020.1774449

Peltzer, A. P. (1899). The origin of anecdotes. Collection of the Kharkov Historical and Philological Society, 11. (In Russian).

Petrovsky, M. S. (1998). Do you know a new anecdote? Book Review, (27), 16-17. (In Russian).

Propp, V. Ya. (1984). Russian fairy tale. Leningrad: Publishing House of the Leningrad State University. (In Russian).

Propp, V. Ya. (1999). Problems of comic and laughter. Ritual laughter in folklore (about the tale of Nesmeyana). Moscow: Labyrinth. (In Russian).

Rushkoff, D. (2003). Media Virus! How pop culture secretly affects your consciousness. Moscow: Ultraculture. (In Russian).

Saricali, M., Satici, S. A., Satici, B., Gocet-Tekin, E., \& Griffiths, M. D. (2020). Fear of COVID-19, Mindfulness, Humor, and Hopelessness: A Multiple Mediation Analysis. International Journal of Mental Health and Addiction. doi: 10.1007/s11469-020-00419-5 
Shepherd, J. (2014, March 16). Why the internet loves cats - not dogs. The Guardian. Retrieved from https://www.theguardian.com/lifeandstyle/2014/mar/16/why-internet-loves-cats-not$\underline{\operatorname{dog} S}$

Shmelev, A. D. \& Shmeleva, E. Ya. (2014). Ethnic stereotypes in Russian jokes. Otechestvennye Zapiski, (4), 167-177. (In Russian).

Shmeleva, E. Ya. \& Shmelev, A. D. (2002). Russian anecdote. Text and speech genre. Moscow: Languages of Slavic culture. (In Russian).

Sirotinina, O. B.(1974). Modern colloquial speech and its features. Moscow: Prosveshcheniye. (In Russian).

Slyshkin, G. G. (2000). From Text to Symbol: Linguocultural Concepts of Precedent Texts in Consciousness and Discourse. Moscow: Academia. (In Russian).

Stankevich, P. A. (2020). Humor will save the world: Internet memes as a public reaction to the global pandemic. Science in a Megapolis, (8), 2. (In Russian).

Stolovich, L. N. (2002). Anecdote and Myth. In Anecdote as a cultural phenomenon (pp. 46-53).

St. Petersburg: St. Petersburg Philosophical Society. (In Russian).

Toporov, V. N. \& Ivanov, V. V. (1974). Research in the field of Slavic antiquities: lexical and phraseological issues of text reconstruction. Moscow: Nauka. (In Russian).

Tyukina, L. A. (2021). Humorous dialogical discourse: anecdotes in the era of COVID-19. Kazan Science, (3), 148-151. (In Russian).

Ukhanova, M. A. (2020). Jokes in digital dimension (linguo-cognitive analysis of jokes on the internet). Cognitive Language Research, (3), 483-488. (In Russian).

Zemskaya, E. A., Kitaygorodskaya, M. V. \& Shiryaev, E. N.(1981). Russian colloquial speech: general issues. Word formation. Syntax. Moscow: Nauka. (In Russian). 